\title{
Long Noncoding RNAs-Crucial Players Organizing the Landscape of the Neuronal Nucleus
}

\author{
Hanna Sas-Nowosielska *(D) and Adriana Magalska *(D) \\ Laboratory of Molecular Bases of Cell Motility, Nencki Institute of Experimental Biology, \\ Polish Academy of Sciences, 02-093 Warsaw, Poland \\ * Correspondence: h.nowosielska@nencki.edu.pl (H.S-N.); a.magalska@nencki.edu.pl (A.M.)
}

check for updates

Citation: Sas-Nowosielska, $\mathrm{H}$.; Magalska, A. Long Noncoding RNAs-Crucial Players Organizing the Landscape of the Neuronal Nucleus. Int. J. Mol. Sci. 2021, 22, 3478. https://doi.org/10.3390/ ijms 22073478

Academic Editor: Giuseppe Biamonti

Received: 25 February 2021

Accepted: 24 March 2021

Published: 27 March 2021

Publisher's Note: MDPI stays neutral with regard to jurisdictional claims in published maps and institutional affiliations.

Copyright: (c) 2021 by the authors. Licensee MDPI, Basel, Switzerland. This article is an open access article distributed under the terms and conditions of the Creative Commons Attribution (CC BY) license (https:// creativecommons.org/licenses/by/ $4.0 /)$.

\begin{abstract}
The ability to regulate chromatin organization is particularly important in neurons, which dynamically respond to external stimuli. Accumulating evidence shows that lncRNAs play important architectural roles in organizing different nuclear domains like inactive chromosome $\mathrm{X}$, splicing speckles, paraspeckles, and Gomafu nuclear bodies. LncRNAs are abundantly expressed in the nervous system where they may play important roles in compartmentalization of the cell nucleus. In this review we will describe the architectural role of lncRNAs in the nuclei of neuronal cells.
\end{abstract}

Keywords: lncRNA; neuronal nucleus; nuclear architecture

\section{Introduction}

The cell nucleus is a highly organized organelle composed of many functional and structural domains (Figure 1). Silent chromatin is compacted in the form of dense chromocenters, localized at the nuclear periphery or adjacent to the nucleolus [1]. The active chromatin compartment faces the interchromatin domain in which nuclear bodies reside [2,3]. Nuclear bodies are membrane-less nuclear subcompartments that form via liquid-liquid phase separation. They are formed by various RNAs and proteins, which together conduct highly specialized processes. Examples include the nucleolus, speckles, paraspeckles, and Promyelocytic leukemia (PML) bodies [4], just to mention a few [5]. Importantly, nuclear architecture is dynamic and directly linked to transcriptional activity [6-8].

Neuronal cells might be of particular interest when it comes to analyzing nuclear architecture and organization, as different types of neurons differ significantly in terms of nuclear size and chromatin organization [9]. They dynamically respond to the external stimuli with a transcriptional burst, and some evidence suggests that neuronal activation is connected with reorganization of the nuclear structure [10-15]. Moreover, neurons seem to differ from other cell types in the composition and organization of at least some of the nuclear bodies [4,16,17].

Recently, long non-coding RNAs (lncRNAs) were described as potent organizers of nuclear architecture $[18,19]$. The nervous system is particularly enriched in IncRNAs. In primates almost $40 \%$ of discovered lncRNAs are expressed specifically in the brain [20]. Compared to protein-coding genes, these non-coding RNAs show lower expression levels, but their expression is more specific in terms of cell type, tissue, and spatiotemporal pattern [21-23]. Importantly, several studies show that dysregulation of lncRNA expression is correlated with aging and neurodevelopmental and cognitive disorders like autism [24-26], Rett syndrome [27], Huntington's disease [28], or Alzheimer's disease [29]. 


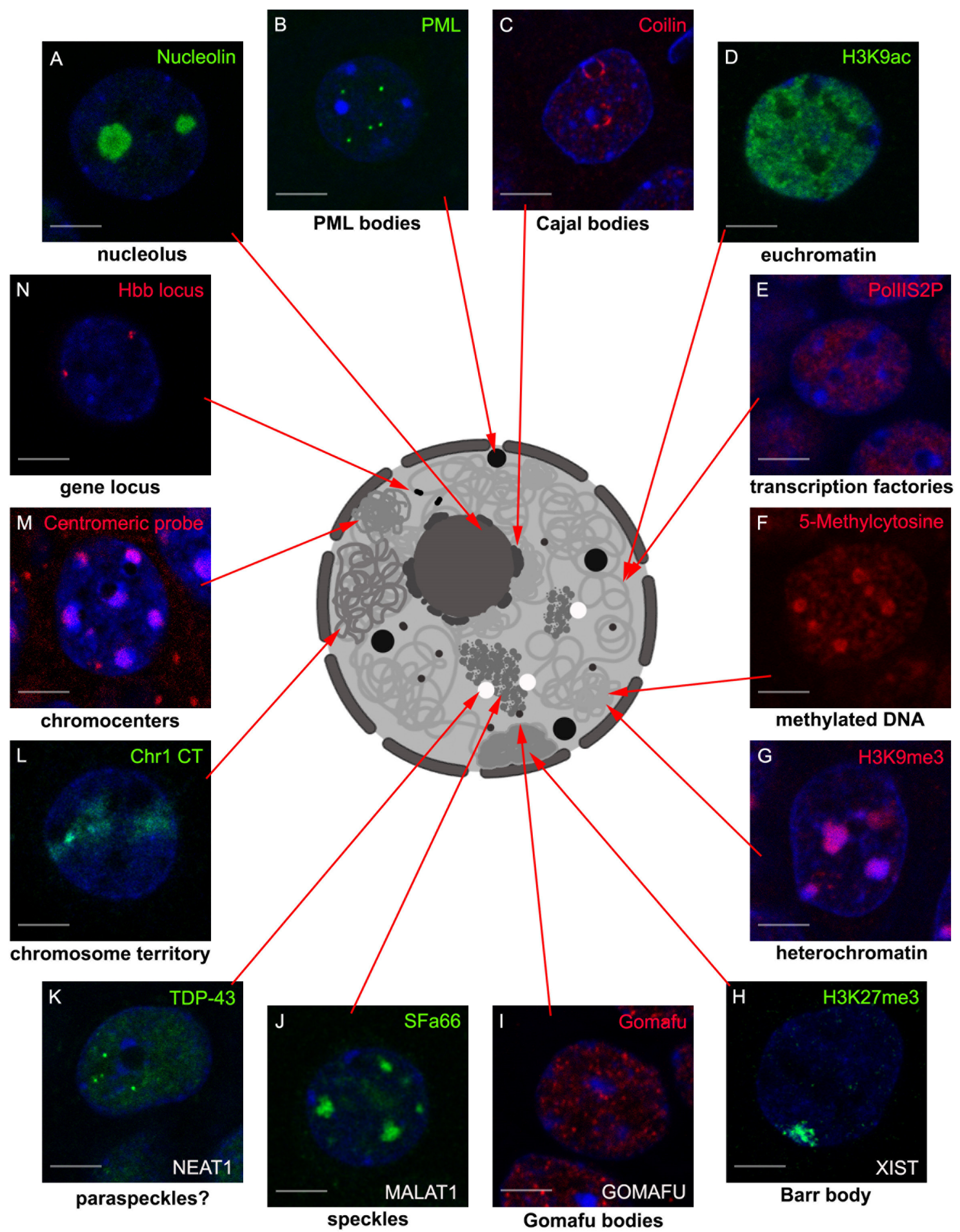

Figure 1. Functional and structural domains of the neuronal cell nucleus. To emphasize the complexity of the neuronal nucleus, different functional and structural assemblies were stained in rodent hippocampal neurons using either antibody recognizing marker proteins or FISH probes complementary to specific sequences. The intricate architecture of the neuronal nucleus consists of nuclear bodies like the nucleolus (A, [30]), and PML (B, [16]) and Cajal bodies (C, [17]); regions of actively transcribed genes marked by the acetylated histones (D) and activated RNA polymerase II (E); and regions of silenced chromatin characterized by methylated DNA (F) and methylated histone H3 (G). It contains also nuclear domains like Barr bodies $(\mathbf{H})$, Gomafu bodies $(\mathbf{I})$, speckles $(\mathbf{J})$, and paraspeckles $(\mathbf{K})$, the assembly and function of which fully rely on lncRNAs (highlighted in white). The genome components like gene loci (L), chromosome territories (M), and repetitive sequences in chromocenters $(\mathbf{N})$ are also shown. Scale bar is $5 \mu \mathrm{m}$. 
LncRNAs can affect nuclear organization by several mechanisms. They may act as epigenetic modulators of chromatin states, thus affecting local chromatin accessibility. Numerous lncRNAs have been shown to interact with epigenetic modifiers like polycomb proteins or methyltransferases and recruit them to particular gene loci [31]. In turn, changes in epigenetic marks affect local chromatin condensation levels [32,33]. One interesting example of such a mechanism is Meg3 and other lncRNAs derived from the Dlk1-Dio3 locus. In motor neurons, these lncRNAs have been found to maintain the repressed state of HOX genes, most likely by guiding polycomb repressive complex (PRC) proteins to this locus [34]. LncRNA can also determine the condensation state of large chromatin domains. One of the best characterized examples is the inactivation of the whole $\mathrm{X}$ chromosome, which is orchestrated by XIST lncRNA (described below) [35]. Additionally, lncRNAs, like MALAT1, can reshape the local nuclear landscape by redistributing particular chromatin domains to active or silent nuclear compartments [36]. Moreover, acting as a molecular scaffold, lncRNA like Gomafu, NEAT1, and MALAT1 recruit proteins to form nuclear bodies like Gomafu bodies, paraspeckles, and speckles, respectively [37-40]. All of these mechanisms might be of particular interest when analyzing changes in nuclear architecture in neuronal cells upon stimulation. Much focus has been put on the regulatory role of lncRNAs in neurons, while a comprehensive review of their structural role is lacking. Here we will focus on lncRNAs, which directly affect the organization of the neuronal nucleus, in particular by participating in nuclear body formation.

\section{LncRNAs Involved in Nuclear Body Formation}

\subsection{XIST and Barr Body}

\subsubsection{The $X$ Chromosome Inactivation}

In 1949, Barr and Berttram [41] described a nuclear body present in neurons of a female cat, which was localized adjacent to the already known nucleolus. The authors suggested that the newly discovered structure, called a nucleolar satellite, was somehow connected with sex chromosomes, as it was virtually nonexistent in neurons derived from male cats. Later studies by Ohno et al. [42] and Lyon [43] showed that this nuclear assembly comprises heterochromatin of one of the $\mathrm{X}$ chromosomes.

Each female cell has only one active $X$ chromosome (Xa), where the second one is transcriptionally inactivated during embryonic development and forms the Barr body, named after its finder. The paternal and maternal copies are randomly silenced in cells of females, which results in the haphazard distribution of actively transcribed genes inherited from both parents on $\mathrm{X}$ chromosomes. The inactivation of one copy of chromosome $\mathrm{X}$ of females is necessary to balance gene expression quantity in males and females. Moreover, in 1967, Susumu Ohno proposed that the monoallelic expression of X-linked genes in mammals should be compensated by the twofold transcriptional up-regulation of the active $X$ in both males and females [44]. However, the recent analysis of 500 public RNAseq datasets from multiple tissues and species showed that in mammals and birds, the ratio of global transcription of sex chromosomes to autosomes is approximately 0.5 , which is inconsistent with Ohno's assumption. In insects, fishes, and flatworms, this ratio is close to 1 [45].

The full dosage compensation is achieved epigenetically on many levels and was first described for Drosophila sex chromosomes by Muller [46]. In fruit flies, contrary to mammals, it relies on the upregulation of the male $X$ chromosome. Here the central role is played by two long non-coding RNAs, roX1 and roX2, which together with five proteins (MSL1, MSL2, MSL3, MLE, and MOF) form the male-specific lethal (MSL) complex. The two lncRNAs are essential for MSL complex assembly and targeting to the X chromosome, where it stimulates transcription of the X-related genes [47].

$\mathrm{X}$ chromosome inactivation $(\mathrm{XCI})$ during development is a dynamic, multi-step, and highly organized process, which is fully dependent on X-inactive specific transcript (XIST), a type of lncRNA. It is initiated at the X-chromosome inactivation center (XIC) of the putative inactive $\mathrm{X}(\mathrm{Xi})$ chromosome, where the XIST gene is localized and expressed [48]. 
Within the core region of the XIC, no protein-coding genes are present; instead, it contains sequences of several lncRNAs. In addition to XIST, this region harbors genes for REPA, TSIX, XITE, and JPX, which are involved in the regulation of XIST expression [49]. TSIX, transcribed from the antisense strand of XIST, is a negative regulator of its expression, and together with XITE controls the allelic choice of the active $\mathrm{X}$ chromosome [50]. The other two IncRNAs, REPA and JPX, are shown to be positive regulators of XIST [51]. After XIST RNA expression and binding at the nucleation center, the silencing spreads throughout the chromosome. Inactivation of the $150 \mathrm{Mb}$ long chromosome is quite a challenge and requires a specific spreading mechanism. Artificial placement of XIC on an autosome results in its silencing induced by the ectopic expression of XIST and coating of DNA by the transcript; however, induced inactivation is not as efficient, suggesting some sequence specificity $[48,52,53]$. Indeed, Gartler and Riggs hypothesized the existence of "way stations", which would be enriched in the X chromosome and boost the spreading of silencing [54]. The later studies of Boyle and colleagues [55] showed that long interspersed elements 1 (LINE-1) are enriched particularly on X chromosomes, which later allowed Mary Lyon to propose a hypothesis about their involvement in X chromosome inactivation [56]. LINEs belong to autonomous, non-LTR retrotransposons, with 6 to $7 \mathrm{~kb}$ long sequences, which constitutes about 17 and 19\% of human and mouse genomes, respectively [57]. The LINE-1 density correlates with the efficiency of XCI spreading, being the highest at XIC [58]. Silent repeats tend to cluster in the interphase nuclei and facilitate the assembly of the heterochromatic compartment, which accelerates XIST and silencing spreading to the whole Xi [59]. The next steps involve exclusion of RNA polymerase II [60] and removal of histone marks characteristic for active promoters and enhancers [60-62] with simultaneous placement of repressive histone tail modifications [62-64] and DNA methylation [65,66], which is all leading to chromatin condensation [53]. The inactive $X$ chromosome becomes tethered to the nuclear periphery [67] or/and nucleolus [68,69]. The cascade of these events is mediated by the proteins, which are recruited to inactivated $X$ chromosome through the various functional domains of XIST transcript, and in the case of nucleolar localization two other lncRNAs, namely FIRRE and DXZ4 [70,71]. Within the XIST sequence, six such domains have been identified. The A-F repeats, which are conserved between humans and mice, overlap with blocks of tandem repeats of unique short sequences, containing motifs specific for RNA binding proteins involved in coordinated silencing of X-linked genes [72].

XIST detectable by RNA-FISH colocalizes with a scaffold attachment factor A (SAFA)/heterogeneous nuclear ribonucleoprotein $\mathrm{U}$ (hnRNPU), a nuclear matrix protein [53]. SAF-A/hnRNPU interacts both with DNA and RNA, forms multimers in the presence of nucleic acids [73], and mediates the retention of many RNAs in the nucleus [74]. Its binding to DNA depends on a conserved SAF-box motif, which interacts cooperatively with a minor-groove of multiple clustered A-tracts of scaffold attachment regions (SAR) DNA [75]. Through RGG (arginine-glycine-glycine), RNA-binding domain SAF-A/hnRNPU binds to the $\mathrm{D}$ repeat of XIST and is indispensable for XIST chromosomal localization [74]. Knocking down of SAF-A/hnRNPU as well as deletion of a D-repeat from XIST results in the dispersion of XIST in the nucleoplasm and lack of Xi silencing and Barr body formation [76]. In turn, the highly conserved repeat A element was shown to be involved both in the regulation of endogenous XIST expression [77] and in the triggering of X-linked gene silencing [78]. The latter is dependent on the direct binding of SPEN protein (known also as SHARP-SMRT/HDAC1-associated repressor protein), the depletion of which similarly reduces the inactivation of $\mathrm{Xi}$ [79]. However, the presence of A repeat element in XIST as well the binding of SPEN is dispensable for XIST chromosomal localization in cis. SPEN is involved in the recruitment of several members of the repressor complexes like NCoR/SMRT and NuRD, and activation of deacetylation [80]. Loss of histone deacetylase HDAC 3 activity was shown to affect $X i$ silencing [62], as deacetylation is crucial and an early step of $X$ chromosome inactivation. Further steps are mediated by the repressive complexes belonging to the Polycomb group, which bind to XIST B and C repeats [63]. Polycomb repressive complex 1 (PRC1) is responsible for the ubiquitination of histone $\mathrm{H} 2 \mathrm{~A}$ on lysine 
119 (H2AK119ub) and recruitment of PRC2, which fully relies on H2AK199ub deposition, whereas PRC2 mediates trimethylation of histone $\mathrm{H} 3$ on lysine 27 (H3K27me3), which in turn signals recruitment of PRC1 complexes, potentiating the Polycomb condensate formation [81]. Overall XIST recruits over 80 proteins [82-84], which regulate multiple and highly organized functions like chromatin remodeling, nuclear matrix binding, and RNA processing, leading to XCI [85].

\subsubsection{Xi Structure and Localization}

Inactivated $X$ chromosome has a very unusual structure, which was shown in detail using chromosomal conformation capture-based techniques [71,86]. Both mouse and human $\mathrm{X}$ consist of two megadomains characterized by the frequent intrachromosomal contacts, which are linked by the hinge region where lncRNA coding microsatellite $D z x 4 / D Z X 4$ repeat is located. The Xa is organized similarly to autosomes into more than 100 topologically associated domains (TADs), on average $1 \mathrm{Mb}$ long, consisting of smaller chromatin loops frequently linking enhancers and promoters. The $\mathrm{Xi}$ megadomains are composed of several dozen super loops (between 7 and $74 \mathrm{Mb}$ long) some of which are anchored at regions containing genes of IncRNA: LOC550643, XIST, DXZ4, and FIRRE. The unique architecture of Xi depends fully on XIST, as inducible XIST expression in male mouse cells resulted in increased interaction frequencies along the chromosome, separation of two megadomains, and a final structure similar to female Xi [87]. Interestingly when the mutated form of XIST lacking A-repeat region, which is responsible for Xi coating and RNA polymerase II exclusion, was induced, male $\mathrm{X}$ chromosome structure was not affected.

The differences in chromatin contacts are reflected in the morphology of chromosome $\mathrm{X}$ territories [88,89]. The observed shape of $\mathrm{Xi}$ chromosome territory (CT) is more rounded and shows a smooth surface when compared with $\mathrm{Xa} C \mathrm{~T}$, which has a flatter shape and exhibits a bigger and more irregular surface. Interestingly, the volume of both chromosomes is quite similar. Teller et al. [90] showed the presence of two structural domains in Xi. Authors measured physical 3D distances between gravity centers of FISH probe intensities used as reference points for differentially-labeled segments. This allowed them to estimate chromatin compaction on $30-50 \mathrm{Mb}, 10 \mathrm{Mb}$, and approximately 1-4 Mb length scales. The higher compaction was observed only for segments bigger than $20 \mathrm{Mb}$. It suggested that the higher condensation in $\mathrm{Xi}$-territory resulted mainly from a regrouping of $\sim 1 \mathrm{Mb}$ chromatin domains rather than from increased compaction within the individual domains. Interestingly, the authors showed that the chromosome territory of the $\mathrm{Xi}$ surpass the region of the Barr body characterized by the XIST binding and highly condensed chromatin. However, gene-poor and gene-rich as well as expressed and repressed segments were evenly distributed within the whole Xi CT. The super-resolution microscopy showed the details of $\mathrm{Xi}$ ultrastructure. It is not a solid, uniformly condensed region of chromatin, but is reminiscent of a sponge-like structure filled with slightly collapsed interchromatin channels. They start at the nuclear pores and meander between areas of the tightly packed chromatin [53]. This again argues for the complete reorganization of chromatin domains within the Xi CT rather than simple condensation leading to higher compaction of chromatin.

As was mentioned, the $\mathrm{Xi}$ was observed for the first time in female cat neurons adjacent to the nucleolus [41]. Later studies have shown that regulation of the $\mathrm{Xi}$ perinucleolar localization is cell cycle-dependent and relies on XIST. The introduction of XIC or XIST itself to autosomes is sufficient for their perinucleolar targeting from the mid to late $S$ phase of the cell cycle [68,91]. Moreover, Yang and colleagues have found the involvement of another lncRNA. Knockdown of Firre in mouse fibroblasts disrupts perinucleolar Xi localization and H3K27me3 levels. However, upon Firre depletion, no reactivation of $\mathrm{X}$-linked genes was observed. Interestingly, in electrically-stimulated motor neurons, the nucleolar satellite observed by Barr and Bertram was moving away from the nucleolus [92]. Similarly, Borden and Manuelidis described the difference in localization of $\mathrm{X}$ chromosomes in electro-defined seizure foci of epileptic patients. As compared to the unaffected cells 
from the neighboring region, both $X$ chromosomes were repositioned towards the nuclear center [93]. Unfortunately, currently there are no data showing how activation induced $\mathrm{Xi}$ repositioning influences $\mathrm{Xi}$ silencing. Numerous studies showed that both $\mathrm{Xa}$ and $\mathrm{Xi}$ are preferably localized at the nuclear periphery. Although all mouse and human chromosomes show the presence of lamina-associated domains (LADs) [94], perinuclear localization of $\mathrm{X} \mathrm{i}$ is also regulated by XIST interaction with membrane attachment nuclear envelope proteins, namely lamin B receptor (LBR), lamina-associated protein 2 (LAP2), and SUN domain-containing protein 2 (SUN2) $[67,84]$. Binding to nuclear lamina through LBR is indispensable for Xi transcriptional inactivation, as knockdown of LBR leads to defects in the silencing of $X$-linked genes [67].

In summary, Xi's unusual ultrastructure and localization to nucleolar and nuclear vicinities is fully dependent on XIST lncRNA.

\subsubsection{Genes That Escape from XCI}

From $3 \%$ to $5 \%$ of genes located on mouse $\mathrm{Xi}$ chromosome are active, and even more so humans, where up to $30 \%$ of genes escape silencing [95-97]. Their expression varies depending on species, tissue, cell type, cell cycle, or developmental stage and can contribute to sex differences in gene expression. Genes with the highest escape level (around $75 \%$ of Xa counterparts) are localized in pseudoautosomal regions PAR1 and PAR2, which are small regions of homology and meiotic pairing with the male $\mathrm{Y}$ chromosome. The rest of the escapees' genes have an expression level 4 or 5 times lower comparing to Xa counterparts. In humans, those active genes are present in clusters; however, in the mouse genome they are dispersed throughout the whole $\mathrm{Xi}$. In general, the gene is considered to be an active escapee, when its expression level from Xi represents at least $10 \%$ of Xa expression. Escaped genes are devoid of the XIST lncRNA coating [98]. They are associated with an open chromatin conformation, RNA polymerase II occupancy, active histone marks, and CTCF protein clustered around and YY1 transcription factor bound at promoters [99-101]. The transcriptomic study of $\mathrm{X}$-chromosome conducted in different regions of the mouse brain [102] uncovered the existence of genomic regions of actively transcribed lncRNAs, which nonrandomly colocalized with protein-coding genes of escapees. This indicates the possible role of additional lncRNAs in the regulation of X-inactivation escape in the mouse brain.

Genes that escape $X$-chromosome inactivation may be particularly important in brain function. In humans, the $X$ chromosome bears about $5 \%$ of the whole genome, yet it contains about $15 \%$ of all known genes associated with intellectual disability. This makes the $\mathrm{X}$ chromosome an attractive target in neurobiological research. There are $141 \mathrm{X}$-linked intellectual disability (XLID) genes, the duplication of which results in some form of mental retardation [103], suggesting their dosage sensitivity. Moreover, detailed analysis of the global expression of X-linked genes showed their higher expression in the brain as compared to other tissues [104]. It seems that the brain is one of the tissues where imbalanced dosage compensation is not well tolerated [105]. The majority of genes that escape silencing on $\mathrm{Xi}$ are involved in brain development and have been implicated in XLID syndromes [95]. An example is KDMC5 coding lysine-specific demethylase 5C (KDM5C, also known as JARID1C or SMCX), the mutations of which cause Claes-Jensen type XLID (CJ-XLID), a rare syndrome accounting for approximately $1-3 \%$ of all XLID cases. KDM5C plays a critical role in constraining transcription during neuronal differentiation and maturation by removing from the histone tail active posttranslational modification, H3K4me3/2 [106]. In addition to severe intellectual disability, CJ-XLID is characterized by autistic behavior, hyperreflexia, emotional outbursts, epileptic seizures, and spastic paraplegia [107,108]. Additionally, KDM5C was shown to be involved in psychiatric disorders. Ji et al. [109] found that the KDM5C and XIST genes are significantly overexpressed in lymphoblastoid cells and postmortem brains of female patients with bipolar disorder or major depression. The authors suggested that over-expressed XIST IncRNA may excessively recruit XIST-binding complexes and by this impair XCI, or the XIST 
overexpression might be the response compensating inefficient $\mathrm{XCI}$. The subtle alteration of XCI, which is the cause or the consequence of XIST over-expression, results in the unbalanced expression of $\mathrm{X}$-linked genes including $\mathrm{X}$ inactivation escapees like KDM5C, which in turn regulates the expression of other genes involved in proper brain function. Interestingly, among genes differentially expressed in women, in those who developed comorbid chronic musculoskeletal pain (CMSP) and posttraumatic stress syndrome (PTSS) in consequence of motor vehicle collision, 40 genes were localized on the $X$ chromosome [110]. Moreover, many of them were previously described as Xi escapees, and their increased expression correlated with the reduction of XIST lncRNA, possible partial derepression of $\mathrm{Xi}$, and later development of CMSP and PTSS.

Another line of evidence of the escapees' importance in brain function comes from the data on sex chromosome aneuploidies, which occur in 1/500 birth in humans. Human karyotype can be described as $46, \mathrm{XX}$ or $46, \mathrm{XY}$, standing for 46 autosomes ad two sex chromosomes. As many as $99 \%$ of embryos with $45, \mathrm{X}$ karyotype die in utero due to defects in placenta development. The surviving $1 \%$ express severe phenotypes of Turner syndrome (TS), including ovarian dysgenesis, short stature, webbed neck, and other physical abnormalities accompanied by deficits in visuospatial reasoning skills, executive function, social cognition, and aberrant brain structure [111]. So far, few specific escapee genes have been found to play a direct role in TS pathology. For example, the SHOX transcription factor, the gene of which is located in the PAR region of chromosome $X$, is responsible for the short stature of TS patients [112]. It is believed that lower expression of escapee genes like KDMC5 and NLGN4X may be engaged in the specific neurocognitive profile of TS [113]. Approximately half of TS patients express $45, \mathrm{X}$ karyotype, and the remaining cases involve sex chromosome mosaicism $(45, \mathrm{X} / 46, \mathrm{XX})$ and/or structural abnormalities of the second $\mathrm{X}$ chromosome, including the ring $\mathrm{X}$ chromosome [114]. The ring $\mathrm{X}$ chromosome often remains active due to the absence of the XIST locus. It has been shown that the presence of the ring $\mathrm{X}$ chromosome was related to cognitive impairments, low IQ scores, and mental retardation, and its size correlated with the severity of neuro-cognitive disabilities. Not only deficiency but also the excess of X chromosomes like in Klinefelter syndrome (KS) has unfavorable consequences for neuro-cognitive functions. A total of $80-90 \%$ of KS patients have classical 47,XXY karyotype, and the rest show even more sex chromosomes (48, XXXY or XXYY, and 49, XXXXY). The supernumerary X chromosomes undergo silencing, except for the escapees' genes. Their altered expression can be involved in the KS phenotype, namely tall stature, gynecomastia, hypogonadism, absent spermatogenesis, changes in brain structures, motor, verbal, and cognition deficits as well as psychiatric disorders from major depression to bipolar disorder to schizophrenia, which are all more frequently diagnosed in KS individuals as compared to the general population [115-117]. All these data clearly show the significant role of XIST and other lncRNAs in the regulation of Xi structure, localization, silencing, and in consequence transcriptional activity of X-linked genes, the alternation of which has deleterious consequences for neuro-cognitive functions.

\subsection{NEAT1 and Paraspeckles}

Nuclear Enriched Autosomal Transcript 1/Nuclear Paraspeckle Assembly Transcript 1 (NEAT1) is one of the key architectural lncRNAs and is responsible for paraspeckle formation. This lncRNA is transcribed by RNA pol II [118], and its expression results in the formation of two transcripts: shorter, polyadenylated NEAT1_1 (3,7 kb in humans) and longer NEAT1_2 (23 kb in humans) [119] The longer transcript is crucial for paraspeckle assembly as it provides a scaffold for paraspeckle protein binding, and its knockdown results in paraspeckle disintegration [118,120-122]. NEAT1_1 is also found in paraspeckles; however, its role is dispensable for their formation or maintenance $[119,123]$. On average particular paraspeckles are formed by 53 NEAT1_2 molecules and 6.5 NEAT1_1 molecules [124]. More than 40 proteins participate in the paraspeckle formation, most of which belong to the mammalian family Drosophila melanogaster behavior human splicing (DBHS) proteins [125]. Several members of this family, like NONO (p54nrb), splicing factor 
proline/glutamine-rich (SFPQ), or FUS are crucial for paraspeckle assembly [126]. Proteins forming paraspeckles usually possess disordered prion-like domains (PDL), which mediate paraspeckle formation via liquid-liquid phase separation [127]. However, to phase separate, these proteins need the locally-increased concentration of scaffold NEAT1 RNA [128]. The interaction between NEAT1_2 and paraspeckle proteins is strong and stable as chemical extraction of NEAT1_2 from paraspeckles requires harsh conditions [124].

Paraspeckles form in a NEAT1_2 transcription-dependent manner near the NEAT1 locus and spread into the nucleoplasm $[118,119]$. The active transcription by RNA Pol II is necessary for paraspeckle formation and maintenance [129]. Studies in human cell lines have shown that the NEAT1 promoter contains binding sites for a variety of transcription factors, and several pathways regulating NEAT1 expression have been described, most of which are connected with stress response [130]. A detailed analysis has shown that the middle part of NEAT1_2 is crucial for paraspeckle assembly, as it provides a scaffold that binds NONO dimers [131]. Binding of NONO to the mid-portion of NEAT1_2 initiates oligomerization of other DHSB proteins, which leads to paraspeckle assembly via a phaseseparation mechanism [131]. Paraspeckles have a spheroidal core-shell structure with a NEAT1_2 folded Vi-shape, so that its $3^{\prime}$ and $5^{\prime}$ ends localize in the shell region of the paraspeckle and its middle part occupies the core region. This organization impacts the distribution of paraspeckle proteins. DHSB proteins colocalize with the NEAT1_2 mid part in the core of paraspeckles, while proteins like TARDBP, RBM14, or BRG1 with other SWI/SNF complex proteins colocalize with the NEAT1 ends $[132,133]$. The number and length of paraspeckles are directly proportional to the level of NEAT1_2 transcription [134]. The use of electron microscopy and histone $\mathrm{H} 3$ detection showed that paraspeckles are mostly depleted of chromatin [133]. However, it is known that NEAT1 may bind active chromatin sites and that its localization changes significantly in response to changes in transcription [135]. Moreover, Chakravarty et al. [136], working on prostate cancer cells, showed that NEAT1_1 can directly interact with promoters of a particular set of genes and induce the active chromatin state favorable for transcription. This is probably mediated via the interaction of NEAT1 with histone $\mathrm{H} 3$ and its modifications H3K9Ac and H3K4me3. This raises the question of whether it fulfills this function independently or as a part of paraspeckles, and consequently, whether paraspeckles are freely diffusing bodies or whether they might bind to the chromatin. Interestingly, a recent study by Grosh et al. has provided evidence that paraspeckles might be tethered to chromatin most probably by forming a triple helix structure [137]. If so, NEAT1 might affect 3D genome architecture by acting as a molecular bridge between chromatin and paraspeckles [22,135].

Paraspeckles form in numerous cell lines and various tissues; however, it seems that they are not vital for cell viability, at least under normal conditions [123]. Till now, paraspeckles have been proposed to (1) be engaged in regulation of transcription, as their presence might affect the availability of transcription factors like NONO and SFPQ $[134,138],(2)$ the regulation of translation, by sequestrating A-to-I hyper-edited RNAs [132], (3) to act as an miRNA sponge, which is mediated by the ability of NEAT1 to bind microRNAs. Consequently, paraspeckles are considered as a "buffer" for various miRNAs, thus affecting the transcription of numerous genes targeted by these miRNAs [139-141]. Importantly, several data show that paraspeckle formation is enhanced by stress conditions, e.g., proteasome inhibition [134,138,142,143].

Despite accumulating data, still very little is known about the role of NEAT1 in the neuronal cell nucleus. The expression of both NEAT1 isoforms in the brain, as estimated by qPCR, is very low $[123,144,145]$. When analyzed separately in the cortex, cerebellum, and spinal cord NEAT1_1 showed modest expression, while NEAT1_2 was hardly detectable [144]. Similar data were obtained when NEAT1 levels were analyzed using FISH in particular parts of the nervous system [144,146]. Analysis of different brain structures confirmed that the dominant form expressed is NEAT1_1 [146]. Furthermore, NEAT1_2 could not be detected in the spinal cord motor neurons. In tissue samples from young and old mice, the only detectable isoform of NEAT1 was NEAT1_1. In contrast to neu- 
rons, single-cell RNA-seq data showed that NEAT1 expression in glial cells is relatively high [144].

Until recently, it has been thought that loss of NEAT1 does not have any significant impact on mouse viability or neuronal functions, though it does impact the development of the corpus luteum [147]. However, a recent study by Kukharsy et al. shed new light on this topic [146]. The group provided evidence that NEAT1 knockout mice show an exaggerated response to physiological stress. In these mice, neurons were hyperexcitable, most probably due to the up-regulated voltage-gated $\mathrm{Na}+$ influx [146]. Moreover, they showed that loss of NEAT1 in the brain leads to the perturbations in alternative splicing, which particularly affects genes related to RNA metabolism, synaptic functions, and neurological diseases [146]. Interestingly, it has been also shown that NEAT1 knockdown alters the expression of genes serving neuroprotective roles, and downregulation of key paraspeckle proteins like NONO or SFPQ negatively affects cell viability [148]. These data suggest that NEAT1 might be important for proper neuronal functioning. However, the analysis of the role of NEAT1 in neuronal activity has given contradicting results. Lipovich et al. [149] provide evidence for activity-dependent NEAT1 function in the human neocortex. Using brain samples from human patients suffering from epilepsy, they identified NEAT1 as one of the IncRNAs upregulated in brain areas of increased activity. Next, using the SH-SY5Y neuroblastoma cell line, they confirmed these results showing that under chronic depolarization, NEAT1 expression was upregulated within $4 \mathrm{~h}$. Those results were, however, contradicted by recent data obtained by Butler et al. [145]. Using Na2 cells and primary hippocampal pyramidal neurons, the group showed that NEAT1 levels decrease after $\mathrm{KCl}$ stimulation. The results were confirmed in the animal model. After $1 \mathrm{~h}$ of contextual fear conditioning, mice had significantly reduced NEAT1 levels in the dorsal hippocampus. The reduction of NEAT1 levels was coupled with an increase in cFos expression both in cultured cells and in mouse brains. Importantly, in adult mice, changes in NEAT1 level were correlated with perturbations in hippocampus-dependent memory formation. The researchers proposed the mechanism according to which NEAT1 affects the chromatin accessibility by interacting with EHMT2 methyltransferase and adding methyl marks to H3K9 [145]. Similar results concerning NEAT1 expression after neuronal activation were obtained by Barry et al. [150]. This group also proposed a possible mechanism by which NEAT1 might affect neuronal excitability [150]. They showed that NEAT1 expression is inversely correlated with the expression of ion channel genes. Moreover, they provided evidence that it can also directly interact with potassium channel interacting proteins. These proteins are one of the key components engaged in regulating neuronal excitability [151]. Residing in the nucleus, NEAT1 may act as a scaffold that upon neuronal activation, releases modulatory proteins to fine-tune the excitatory response [150]. Transient downregulation of NEAT1 upon neuronal activation might induce the release of potassium channel proteins from the nucleus into the cytosol. This data shows that NEAT1 is involved in processes crucial for the proper functioning of neurons. Additional evidence that NEAT1 is important for these cells comes from the analysis of neuronal aging and pathological conditions. Accumulating data show that NEAT1 can be dysregulated in aging brains and several neuronal diseases, such as Huntington's disease, amyotrophic lateral sclerosis (ALS), or frontotemporal dementia (FTD) $[145,148,152-154]$. However, in different diseases, NEAT1 might be either up- or down-regulated. The imbalance in NEAT1 expression is often accompanied by mutations in various paraspeckle proteins like TDP-43 or FUS [144,154-156]. One of the best-characterized examples is ALS and FTD. It has been shown that in motor neurons of ALS and FTD patients as well as mouse models of these diseases, NEAT1 becomes upregulated and is excessively bound to TDP-43, which contributes to decreased neuronal cell viability [154,157]. Interestingly, the authors checked whether NEAT1 knockdown could reverse this effect, and it appeared to have a similarly negative impact on neuronal viability as upregulation. This led them to the conclusion that any imbalance in NEAT1 expression in motor neurons might have negative impact on the cell viability [154] Similarly, increased expression of NEAT1 has been observed in a mouse model of Huntington's disease and 
ataxia types 1,2, and 7 [148]. On the other hand, analysis of a mouse model of the AD dataset from the National Center for Biotechnology Information (NCBI) database showed that NEAT1 is downregulated in the hippocampus at the early stages of AD [158] These data highlight that although a very low NEAT1 expression level is important for neurons, its imbalance might contribute to the development of a pathological phenotype.

It seems that at least some of these diseases are accompanied by de novo paraspeckle formation in the neuronal cell nucleus. Probably the first evidence for the possible formation of paraspeckles in neuronal cells was shown by Nishimoto et al., who analyzed paraspeckles in amyotrophic lateral sclerosis (ALS) tissue samples from mice and humans [144]. Shelkovnikova et al. further showed that while normal neurons lack paraspeckles, they are present in $\sim 40 \%$ of motor neurons of patients with ALS. They also showed that loss of TDP-43 protein is sufficient to stimulate paraspeckle formation. The probable underlying mechanism involves compromised miRNA biogenesis or activation of the dsRNA response [159]. These results point to the possible role of paraspeckles in regulating the miRNA pathway, which is in line with the evidence obtained on the cell lines [141]. Interestingly, also in the Huntington's disease model, enlarged paraspeckles have been observed [148], which suggests that paraspeckles might play a neuroprotective role in stress conditions. On the other hand, it remains unclear how the nucleation of paraspeckles is regulated. If active transcription of NEAT1 is necessary for paraspeckles to form, then what level of this transcription will result in the appearance of paraspeckles?

Together this data show that though barely detectable in the neuronal cell nucleus, NEAT1 plays an important role in neuronal activation, the fundamental process in the neuronal cell. It seems that NEAT1 acts independently of paraspeckles, as available data show that normal neurons lack these nuclear domains. This suggests that at basal conditions (silent neurons), the main role is played by the NEAT1_1 transcript. However, under stress conditions, the cell switches to longer NEAT1 isoform synthesis. The appearance of NEAT1_2 leads to nucleation of paraspeckles, which help the cell to restore balance.

\subsection{MALAT1 and Nuclear Speckles}

MALAT1 (metastasis-associated lung adenocarcinoma transcript 1) was originally identified in a screen for RNAs, the levels of which were altered in early-stage lung cancers, and was found to be upregulated in tumors with a high ability to metastasize [160] Unlike most of the known lncRNAs, MALAT1 has high sequence conservation in vertebrates [161]. The MALAT1 gene is transcribed by RNA pol II, and its transcription gives rise to $\sim 7 \mathrm{~kb}$ lncRNA. It is highly enriched in nuclear bodies called splicing speckles, where it might play a role in regulating the protein composition of these nuclear bodies [162].

Splicing speckles are liquid-like nuclear bodies enriched in serine/arginine (SR) splicing factors and SR-like proteins. The human interphase nucleus contains $20-40$ speckles, ranging in size from 0.5 to several micrometers in diameter [163]. Both speckle number and shape respond dynamically to changes in transcriptional activity [164-166]. Speckles have complex protein compositions including the aforementioned splicing factors, transcription factors, $3^{\prime}$ end RNA processing factors, proteins engaged in mRNA export, and enzymes regulating splicing machinery [163]. Their composition suggests that they may orchestrate crucial steps of transcription [167]. Moreover within speckles, apart from MALAT1, different types of RNAs can be found, including pre-mRNAs and snoRNAs [167-169]. Their complex composition is reflected in their organization, in which SR and SR-like proteins form the core of the speckle, and snRNAs and MALAT1 are enriched in the speckle periphery [170].

It has been shown that actively transcribed genes can associate with nuclear speckles [171-179], and this association increases their transcription rate [180]. The development of novel 3D interaction analysis techniques like split-pool recognition of interactions by tag extension (SPRITE), or tyramide signal amplification (TSA)-seq has revealed that genespeckle association is a common event. This leads to the suggestion that splicing speckles play an important role in shaping 3D chromatin architecture by acting as hubs, which 
recruit active genes and bring in close spatial proximity genes laying on different chromosomes [181,182]. Interestingly, the transcription of speckle-associated genes and the accumulation of RNA in speckles affects their size [170].

As a component of splicing speckles, MALAT1 has been shown to play various roles. Due to its ability to affect the levels of speckle components and interact with different speckle proteins, it participates in regulating speckle number and organization $[162,170,183]$. It can serve as a "sponge" for splicing factors, thus modulating the recruitment of SR splicing factors to an active transcription site $[36,38]$ and regulating spliceosome composition within speckles, which affects alternative splicing. By its ability to bind miRNAs, MALAT1 can also regulate their availability for the downstream processes [36]. Though the detailed mechanism is unknown, it seems possible that MALAT1 regulates the levels of miRNA while being associated with nuclear speckles, as miRNA processing machinery was found in splicing speckles [184]. Interestingly, though engaged in multiple speckle-related processes, MALAT1 knockout has no obvious effect on speckle formation and maintenance $[185,186]$. Thus, it might be dispensable for their organization. On the contrary, a recent study by Nguyen et al. [187] has shown that deletion of the SINEB1 element from MALAT1 significantly affected speckle morphology. This deletion perturbed MALAT1-protein interactions, indicating that they might be important in speckle stabilization. It also resulted in the mislocalization of MALAT1 to the cytoplasm, where it "hijacked" speckle protein TDP-43, leading to the formation of the cytotoxic TDP-43 inclusions. These results suggested that MALAT1 might be also important for proteostasis [187]. MALAT1 binds numerous active gene sites and has been shown to control gene expression in cis $[186,188]$ and trans [135]. Due to its ability to interact directly with chromatin, MALAT1 might tether splicing speckles to chromatin fiber [135]. Accordingly, MALAT1, together with another IncRNA, TUG1, has been shown to affect the 3D nuclear organization. Both lncRNAs act to relocate the growth control genes from the repressing environment of polycomb bodies to the transcriptionally active milieu of splicing speckles by interacting with Polycomb 2 (Pc2) protein present on gene promoters [189]. In this way, both lncRNAs and Pc2 provide a mechanism that determines the relative positioning of particular genes with respect to subnuclear architectural structures [189].

Little is known about the role of MALAT1 in neuronal cell nuclei. MALAT1-enriched nuclear speckles are a common feature of the neuronal nucleus [190], where they form a dynamic domain that reorganizes in response to external cues [191]. Considering speckle's role as conductor of transcription, they should be particularly important in neurons, which dynamically change their transcriptome in response to stimulation. Accordingly, MALAT1 is expressed in neurons at high levels $[38,145,186]$. It has been shown that downregulation of MALAT1 in primary cortical neurons results in their increased excitability [192]. Results obtained by Lipovich et al. showed that MALAT1 is upregulated in high-activity areas of the neocortex in patients with epilepsy, and its expression pattern suggested that it is engaged in the regulation of activity-dependent genes [149]. Moreover, knock-out of MALAT1 in cultured hippocampal neurons led to decreased synaptic density [38], which suggests that it also plays a role in regulating genes involved in synapse formation/maintenance. Nonetheless, despite its obvious role in neurons, it was shown that its knockout does not affect mouse pre- and postnatal development [186]. However, it is tempting to speculate that it might affect the behavior of these animals, but unfortunately such data are lacking.

Several papers point to the importance of the regulatory role of MALAT1 in neurons due to its ability to sponge miRNAs. The interaction of MALAT1 with miR-30 is involved in the regulation of neurite outgrowth in hippocampal neurons [193]. It also plays a protective role in ischemic stroke. Both in cultured primary cerebral cortex neurons and the mouse ischemic stroke model, MALAT1 was downregulated, which led to an increase in miR-30a miRNA and, in consequence, inhibition of autophagic pathways [194]. MALAT1 levels were significantly elevated in the hippocampi of rats with epilepsy, and its downregulation exerted a protective effect on neuronal survival [195]. Similarly, MALAT1 is upregulated in the PD mouse model, and its ability to sponge miR-124 was one of the causes of neuronal 
apoptosis [196]. On the other hand, studies on the AD rat model showed that the level of MALAT1 was significantly decreased [197]. Its overexpression prevented neuronal apoptosis and promoted neurite outgrowth [198]. Thus, it seems that in different neuronal diseases, MALAT1 might play contradictory roles, though at least some of them, e.g., MALAT1-miRNA interaction, might have a neuroprotective function [194,197].

\subsection{Gomafu and Gomafu Bodies}

The study of Sone and colleagues [40] showed that a novel lncRNA, GOMAFU, also known as MIAT (myocardial infarction associated transcript) or RNCR2 (retinal non-coding RNA 2), was highly expressed in differentiating neural progenitor cells. In the mature brain, GOMAFU was detected in a subset of postmitotic neurons including retinal ganglion and amacrine cells of the retina, and pyramidal cells in the cerebral cortex layer $\mathrm{V}$ and CA1 region of the hippocampus. It formed distinct nuclear bodies but yet failed to colocalize with markers of known nuclear domains like PML and Cajal bodies, nuclear speckles, paraspeckles, or nucleolus. Therefore, the authors suggested that GOMAFU forms a new kind of nuclear domain embedded in the nuclear matrix. Unlike speckles and paraspeckles, GOMAFU body formation and maintenance were not dependent on transcriptional activity. Later studies have suggested that GOMAFU is involved in the regulation of several neuronal processes like retinal cell fate specification [199], neuronal and glial cell differentiation [200,201], the survival of newborn neurons in corticogenesis [202], and cognitive decline in aging $[153,203]$. Moreover, differential screening showed its higher expression in the nucleus accumbens of heroin- and cocaine-addicted users [204]. Knockout mice completely devoid of GOMAFU expression did not present any developmental drawbacks but exhibited hyperactive behavior and sensitivity to psychostimulants, which was associated with an increased extracellular concentration of dopamine in the same brain region known to be involved in addiction [205]. Transcriptomic analysis showed changed expression of only 19 transcripts; however, among them were several genes involved in important neuronal functions. For example, $\mathrm{KO}$ mice had decreased expression of CEBPB (CCAAT-enhancer-binding protein), a transcription factor implicated in memory consolidation in the hippocampus. Interestingly the expression of GOMAFU is downregulated in cortical neurons in the response to activation. Additionally, its decreased level was found in the cortical gray matter of the superior temporal gyrus of schizophrenia patients [206]. The loss-of-function mutations of GOMAFU lead to the alternative splicing patterns in transcripts of the synaptic plasticity-related genes. As GOMAFU was shown to bind splicing factors QKI and SRSF1 (serine/arginine-rich splicing factor 1), it is proposed to regulate alternative splicing of transcripts involved in neuronal activation and pathology of schizophrenia. Studies of the Nakagawa group $[205,206]$ seem to confirm this scenario, as they demonstrated GOMAFU interaction with two other well-recognized splicing factors, SF1 and CELF3. Both proteins assembled into a novel nuclear domain, called by the authors CS bodies, which were sensitive to transcription inhibition and RNAse treatment. Surprisingly, despite the dependence between the expression of CELF3 protein and transcription of GOMAFU, CS bodies did not contain GOMAFU RNA itself. All the aforementioned publications point out the activity-dependent function of GOMAFU in the postmitotic neurons. Even though the exact molecular pathways are poorly recognized, this abundant IncRNA, which forms a unique nuclear domain in a specific subset of mature neurons, plays an important role in the regulation of genes involved in neuronal plasticity.

\section{Perspective}

In summary, we have described how lncRNAs shape the neuronal nucleus architecture and stand behind its dynamic plasticity. In the context of neuron-related diseases, we discuss how lncRNA imbalances might contribute to the pathological phenotype by affecting the organization of subnuclear domains. It is not yet clear how nuclear architecture translates to gene expression, but accumulating data point to a link between them. 
The significance and exact molecular mechanisms underlying lncRNA function in neuronal plasticity are still far from understood. Altogether, these studies indicate that lncRNAs and RNA binding proteins reside in specific nuclear compartments that dynamically respond to neuronal stimulation.

Funding: This work was supported by the National Science Centre, grant no. UMO-2015/18/E/NZ3/ 00730.

Institutional Review Board Statement: Not applicable.

Informed Consent Statement: Not applicable.

Data Availability Statement: Not applicable.

Conflicts of Interest: The authors declare no conflict of interest.

\section{References}

1. Cremer, T.; Cremer, M.; Hübner, B.; Strickfaden, H.; Smeets, D.; Popken, J.; Sterr, M.; Markaki, Y.; Rippe, K.; Cremer, C. The 4D nucleome: Evidence for a dynamic nuclear landscape based on co-aligned active and inactive nuclear compartments. FEBS Lett. 2015, 589, 2931-2943. [CrossRef]

2. Cremer, T.; Cremer, M.; Hübner, B.; Silahtaroglu, A.; Hendzel, M.; Lanctôt, C.; Strickfaden, H.; Cremer, C. The Interchromatin Compartment Participates in the Structural and Functional Organization of the Cell Nucleus. BioEssays 2020, 42, 1-18. [CrossRef] [PubMed]

3. Staněk, D.; Fox, A. Nuclear bodies: News insights into structure and function. Curr. Opin. Cell Biol. 2017, 46, 94-101. [CrossRef] [PubMed]

4. Hall, M.H.; Magalska, A.; Malinowska, M.; Ruszczycki, B.; Czaban, I.; Patel, S.; Ambrożek-Latecka, M.; Zołocińska, E.; Broszkiewicz, H.; Parobczak, K.; et al. Localization and regulation of PML bodies in the adult mouse brain. Brain Struct. Funct. 2016, 221, 2511-2525. [CrossRef] [PubMed]

5. Zhu, L.; Brangwynne, C.P. Nuclear bodies: The emerging biophysics of nucleoplasmic phases. Curr. Opin. Cell Biol. 2015, 34, 23-30. [CrossRef]

6. van Steensel, B.; Furlong, E.E.M. The role of transcription in shaping the spatial organization of the genome. Nat. Rev. Mol. Cell Biol. 2019, 20, 327-337. [CrossRef]

7. Heinz, S.; Texari, L.; Hayes, M.G.B.; Urbanowski, M.; Chang, M.W.; Givarkes, N.; Rialdi, A.; White, K.M.; Albrecht, R.A.; Pache, L.; et al. Transcription Elongation Can Affect Genome 3D Structure. Cell 2018, 174, 1522-1536.e22. [CrossRef]

8. Weipoltshammer, K.; Schöfer, C. Morphology of nuclear transcription. Histochem. Cell Biol. 2016, 145, 343-358. [CrossRef]

9. Solovei, I.; Kreysing, M.; Lanctôt, C.; Kösem, S.; Peichl, L.; Cremer, T.; Guck, J.; Joffe, B. Nuclear Architecture of Rod Photoreceptor Cells Adapts to Vision in Mammalian Evolution. Cell 2009, 137, 356-368. [CrossRef]

10. Benito, E.; Barco, A. The Neuronal Activity-Driven Transcriptome. Mol. Neurobiol. 2015, 51, 1071-1088. [CrossRef]

11. Yap, E.L.; Greenberg, M.E. Activity-Regulated Transcription: Bridging the Gap between Neural Activity and Behavior. Neuron 2018, 100, 330-348. [CrossRef]

12. Billia, F.; Baskys, A.; Carlen, P.L.; De Boni, U. Rearrangement of centromeric satellite DNA in hippocampal neurons exhibiting long-term potentiation. Mol. Brain Res. 1992, 14, 101-108. [CrossRef]

13. Tao-Cheng, J.H. Stimulation-induced structural changes at the nucleus, endoplasmic reticulum and mitochondria of hippocampal neurons. Mol. Brain 2018, 11, 1-14. [CrossRef] [PubMed]

14. Crepaldi, L.; Policarpi, C.; Coatti, A.; Sherlock, W.T.; Jongbloets, B.C.; Down, T.A.; Riccio, A. Binding of TFIIIC to SINE Elements Controls the Relocation of Activity-Dependent Neuronal Genes to Transcription Factories. PLoS Genet. 2013, 9. [CrossRef] [PubMed]

15. Walczak, A.; Szczepankiewicz, A.A.; Ruszczycki, B.; Magalska, A.; Zamlynska, K.; Dzwonek, J.; Wilczek, E.; Zybura-Broda, K.; Rylski, M.; Malinowska, M.; et al. Novel higher-order epigenetic regulation of the Bdnf gene upon seizures. J. Neurosci. 2013, 33, 2507-2511. [CrossRef] [PubMed]

16. Salomoni, P.; Betts-Henderson, J. The role of PML in the nervous system. Mol. Neurobiol. 2011, 43, 114-123. [CrossRef]

17. Lafarga, M.; Tapia, O.; Romero, A.M.; Berciano, M.T. RNA Biology Cajal bodies in neurons. 2016. [CrossRef]

18. Yamazaki, T.; Nakagawa, S.; Hirose, T. Architectural RNAs for Membraneless Nuclear Body Formation. Cold Spring Harb. Symp. Quant. Biol. 2019, 84, 227-237. [CrossRef]

19. Thakur, J.; Henikoff, S. Architectural RNA in chromatin organization. Biochem. Soc. Trans. 2020, 48, 1967-1978. [CrossRef] [PubMed]

20. Derrien, T.; Johnson, R.; Bussotti, G.; Tanzer, A.; Djebali, S.; Tilgner, H.; Guernec, G.; Martin, D.; Merkel, A.; Knowles, D.G.; et al. The GENCODE v7 catalog of human long noncoding RNAs: Analysis of their gene structure, evolution, and expression. Genome Res. 2012, 22, 1775-1789. [CrossRef] 
21. Gendron, J.; Colace-Sauty, C.; Beaume, N.; Cartonnet, H.; Guegan, J.; Ulveling, D.; Pardanaud-Glavieux, C.; Moszer, I.; Cheval, H.; Ravassard, P. Long non-coding RNA repertoire and open chromatin regions constitute midbrain dopaminergic neuron - specific molecular signatures. Sci. Rep. 2019, 9, 1409. [CrossRef]

22. Zimmer-Bensch, G. Emerging Roles of Long Non-Coding RNAs as Drivers of Brain Evolution. Cells 2019, 8, 1399. [CrossRef] [PubMed]

23. Kadakkuzha, B.M.; Liu, X.-A.; Mccrate, J.; Shankar, G.; Rizzo, V.; Afinogenova, A.; Young, B.; Fallahi, M.; Carvalloza, A.C.; Raveendra, B.; et al. Transcriptome analyses of adult mouse brain reveal enrichment of lncRNAs in specific brain regions and neuronal populations. 2015. [CrossRef]

24. Ziats, M.N.; Rennert, O.M. Aberrant Expression of Long Noncoding RNAs in Autistic Brain. J. Mol. Neurosci. 2013, 49, 589-593. [CrossRef] [PubMed]

25. Cogill, S.B.; Srivastava, A.K.; Yang, M.Q.; Wang, L. Co-expression of long non-coding RNAs and autism risk genes in the developing human brain. BMC Syst. Biol. 2018, 12, 91. [CrossRef] [PubMed]

26. Parikshak, N.N.; Swarup, V.; Belgard, T.G.; Irimia, M.; Ramaswami, G.; Gandal, M.J.; Hartl, C.; Leppa, V.; Ubieta, L.D.L.T.; Huang, J.; et al. Genome-wide changes in lncRNA, splicing, and regional gene expression patterns in autism. Nature 2016, 540, 423-427. [CrossRef]

27. Petazzi, P.; Sandoval, J.; Szczesna, K.; Jorge, O.C.; Roa, L.; Sayols, S.; Gomez, A.; Huertas, D.; Esteller, M. Dysregulation of the long non-coding RNA transcriptome in a Rett syndrome mouse model. RNA Biol. 2013, 10, 1197-1203. [CrossRef] [PubMed]

28. Johnson, R. Long non-coding RNAs in Huntington's disease neurodegeneration. Neurobiol. Dis. 2012, 46, 245-254. [CrossRef]

29. Idda, M.L.; Munk, R.; Abdelmohsen, K.; Gorospe, M. Noncoding RNAs in Alzheimer's disease. Wiley Interdiscip. Rev. RNA 2018, 9, e1463. [CrossRef]

30. Iarovaia, O.V.; Minina, E.P.; Sheval, E.V.; Onichtchouk, D.; Dokudovskaya, S.; Razin, S.V.; Vassetzky, Y.S. Nucleolus: A Central Hub for Nuclear Functions. Trends Cell Biol. 2019, 29, 647-659. [CrossRef] [PubMed]

31. Joh, R.I.; Palmieri, C.M.; Hill, I.T.; Motamedi, M. Regulation of histone methylation by noncoding RNAs. Biochim. Biophys. Acta Gene Regul. Mech. 2014, 1839, 1385-1394. [CrossRef]

32. Villaseñor, R.; Baubec, T. Regulatory mechanisms governing chromatin organization and function. Curr. Opin. Cell Biol. 2021, 70, 10-17. [CrossRef] [PubMed]

33. Zhao, Y.; Sun, H.; Wang, H. Long noncoding RNAs in DNA methylation: New players stepping into the old game. Cell Biosci. 2016, 6, 1-6. [CrossRef] [PubMed]

34. Yen, Y.P.; Hsieh, W.F.; Tsai, Y.Y.; Lu, Y.L.; Liau, E.S.; Hsu, H.C.; Chen, Y.C.; Liu, T.C.; Chang, M.; Li, J.; et al. Dlk1-Dio3 locus-derived IncRNAs perpetuate postmitotic motor neuron cell fate and subtype identity. Elife 2018, 7. [CrossRef] [PubMed]

35. Mozdarani, H.; Ezzatizadeh, V.; Rahbar Parvaneh, R. The emerging role of the long non-coding RNA HOTAIR in breast cancer development and treatment. J. Transl. Med. 2020, 18, 1-15. [CrossRef]

36. Arun, G.; Aggarwal, D.; Spector, D.L. MALAT1 Long Non-Coding RNA: Functional Implications. Non-Coding RNA 2020, 6, 22. [CrossRef]

37. Chujo, T.; Yamazaki, T.; Hirose, T. Architectural RNAs (arcRNAs): A class of long noncoding RNAs that function as the scaffold of nuclear bodies. Biochim. Biophys. Acta Gene Regul. Mech. 2016, 1859, 139-146. [CrossRef]

38. Bernard, D.; Prasanth, K.V.; Tripathi, V.; Colasse, S.; Nakamura, T.; Xuan, Z.; Zhang, M.Q.; Sedel, F.; Jourdren, L.; Coulpier, F.; et al. A long nuclear-retained non-coding RNA regulates synaptogenesis by modulating gene expression. EMBO J. 2010, 29, 3082-3093. [CrossRef]

39. Smith, K.P.; Hall, L.L.; Lawrence, J.B. Nuclear hubs built on RNAs and clustered organization of the genome. Curr. Opin. Cell Biol. 2020, 64, 67-76. [CrossRef]

40. Sone, M.; Hayashi, T.; Tarui, H.; Agata, K.; Takeichi, M.; Nakagawa, S. The mRNA-like noncoding RNA Gomafu constitutes a novel nuclear domain in a subset of neurons. J. Cell Sci. 2007, 120, 2498-2506. [CrossRef]

41. Barr, M.L.; Bertram, E.G. A morphological distinction between neurones of the male and female, and the behaviour of the nucleolar satellite during accelerated nucleoprotein synthesis. Nature 1949, 163, 676-677. [CrossRef]

42. Ohno, S.; Kaplan, W.D.; Kinosita, R. Formation of the sex chromatin by a single X-chromosome in liver cells of Rattus norvegicus. Exp. Cell Res. 1959, 18, 415-418. [CrossRef]

43. Lyon, M. Gene Action in the X-chromosome of the Mouse (Mus musculus L.). Nature 1961, 190, 372-373. [CrossRef] [PubMed]

44. Ohno, S. Sex Chromosomes and Sex-linked Genes. Springer: Berlin/Heidelberg, Germany, 1967; ISBN 9783642881800.

45. Chen, J.; Wang, M.; He, X.; Yang, J.-R.; Chen, X. The Evolution of Sex Chromosome Dosage Compensation in Animals. J. Genet. Genomics 2020. [CrossRef]

46. Muller, H.J. Evidence of the precision of genetic adaptation. Harvey Lect Ser. 1948, 43, 165-229.

47. Lucchesi, J.C.; Kuroda, M.I. Dosage compensation in drosophila. Cold Spring Harb. Perspect. Biol. 2015, 7, 1-21. [CrossRef]

48. Herzing, L.B.K.; Romer, J.T.; Horn, J.M.; Ashworth, A. Xist has properties of the X-chromosome inactivation centre. Nature 1997, 386, 272-275. [CrossRef]

49. Lee, J.T.; Lu, N.; Han, Y. Genetic analysis of the mouse X inactivation center defines an 80-kb multifunction domain. Proc. Natl. Acad. Sci. USA 1999, 96, 3836-3841. [CrossRef]

50. Lee, J.T. Molecular biology: Regulation of X-chromosome counting by Tsix and Xite sequences. Science 2005, 309, 768-771. [CrossRef] 
51. Tian, D.; Sun, S.; Lee, J.T. The long noncoding RNA, Jpx, is a molecular switch for X chromosome inactivation. Cell 2010, 143, 390-403. [CrossRef]

52. Lee, J.T.; Jaenisch, R. Long-range cis effects of ectopic X-inactivation centres on a mouse autosome. Nature 1997, 386, 275-279. [CrossRef] [PubMed]

53. Smeets, D.; Markaki, Y.; Schmid, V.J.; Kraus, F.; Tattermusch, A.; Cerase, A.; Sterr, M.; Fiedler, S.; Demmerle, J.; Popken, J.; et al. Three-dimensional super-resolution microscopy of the inactive $\mathrm{X}$ chromosome territory reveals a collapse of its active nuclear compartment harboring distinct Xist RNA foci. Epigenet. Chromatin 2014, 7, 1-27. [CrossRef]

54. Gartler, S.M.; Riggs, A.D. Mammalian X-chromosome inactivation. Annu. Rev. Genet. 1983, 17, 155-190. [CrossRef]

55. Boyle, A.L.; Ballard, S.G.; Ward, D.C. Differential distribution of long and short interspersed element sequences in the mouse genome: Chromosome karyotyping by fluorescence in situ hybridization. Proc. Natl. Acad. Sci. USA 1990, 87, 7757-7761. [CrossRef] [PubMed]

56. Lyon, M.F. X-chromosome inactivation: A repeat hypothesis. Cytogenet. Cell Genet. 1998, 80, 133-137. [CrossRef] [PubMed]

57. Paço, A.; Adega, F.; Chaves, R. LINE-1 retrotransposons: From "parasite" sequences to functional elements. J. Appl. Genet. 2015, 56, 133-145. [CrossRef]

58. Bailey, J.A.; Carrel, L.; Chakravarti, A.; Eichler, E.E. Molecular evidence for a relationship between LINE-1 elements and X chromosome inactivation: The Lyon repeat hypothesis. Proc. Natl. Acad. Sci. USA 2000, 97, 6634-6639. [CrossRef]

59. Chow, J.C.; Ciaudo, C.; Fazzari, M.J.; Mise, N.; Servant, N.; Glass, J.L.; Attreed, M.; Avner, P.; Wutz, A.; Barillot, E.; et al. LINE-1 activity in facultative heterochromatin formation during $X$ chromosome inactivation. Cell 2010, 141, 956-969. [CrossRef]

60. Chaumeil, J.; Okamoto, I.; Guggiari, M.; Heard, E. Integrated kinetics of X chromosome inactivation in differentiating embryonic stem cells. Cytogenet. Genome Res. 2002, 99, 75-84. [CrossRef]

61. Jeppesen, P.; Turner, B.M. The inactive $\mathrm{X}$ chromosome in female mammals is distinguished by a lack of histone H4 acetylation, a cytogenetic marker for gene expression. Cell 1993, 74, 281-289. [CrossRef]

62. Żylicz, J.J.; Bousard, A.; Žumer, K.; Dossin, F.; Mohammad, E.; da Rocha, S.T.; Schwalb, B.; Syx, L.; Dingli, F.; Loew, D.; et al. The Implication of Early Chromatin Changes in X Chromosome Inactivation. Cell 2019, 176, 182-197.e23. [CrossRef]

63. Plath, K.; Fang, J.; Mlynarczyk-Evans, S.K.; Cao, R.; Worringer, K.A.; Wang, H.; Zhang, Y. Role of histone H3 lysine 27 methylation in $\mathrm{X}$ inactivation. Science 2003, 300, 131-135. [CrossRef]

64. Heard, E.; Rougeulle, C.; Arnaud, D.; Avner, P.; Allis, C.D.; Spector, D.L. Methylation of histone H3 at Lys-9 Is an early mark on the $\mathrm{X}$ chromosome during $\mathrm{X}$ inactivation. Cell 2001, 107, 727-738. [CrossRef]

65. Duncan, C.G.; Grimm, S.A.; Morgan, D.L.; Bushel, P.R.; Bennett, B.D.; Roberts, J.D.; Tyson, F.L.; Merrick, B.A.; Wade, P.A. Dosage compensation and DNA methylation landscape of the $\mathrm{X}$ chromosome in mouse liver. Sci. Rep. 2018, 8, 1-17. [CrossRef]

66. Gdula, M.R.; Nesterova, T.B.; Pintacuda, G.; Godwin, J.; Zhan, Y.; Ozadam, H.; McClellan, M.; Moralli, D.; Krueger, F.; Green, C.M.; et al. The non-canonical SMC protein SmcHD1 antagonises TAD formation and compartmentalisation on the inactive $\mathrm{X}$ chromosome. Nat. Commun. 2019, 10, 1-14. [CrossRef] [PubMed]

67. Chen, C.K.; Blanco, M.; Jackson, C.; Aznauryan, E.; Ollikainen, N.; Surka, C.; Chow, A.; Cerase, A.; McDonel, P.; Guttman, M. Xist recruits the $X$ chromosome to the nuclear lamina to enable chromosome-wide silencing. Science 2016, 354, 468-472. [CrossRef] [PubMed]

68. Zhang, L.-F.; Huynh, K.D.; Lee, J.T. Perinucleolar targeting of the inactive X during S phase: Evidence for a role in the maintenance of silencing. Cell 2007, 129, 693-706. [CrossRef] [PubMed]

69. Bourgeois, C.A.; Laquerriere, F.; Hemon, D.; Hubert, J.; Bouteille, M. New data on the in-situ position of the inactive X chromosome in the interphase nucleus of human fibroblasts. Hum. Genet. 1985, 69, 122-129. [CrossRef]

70. Yang, F.; Deng, X.; Ma, W.; Berletch, J.B.; Rabaia, N.; Wei, G.; Moore, J.M.; Filippova, G.N.; Xu, J.; Liu, Y.; et al. The lncRNA Firre anchors the inactive $X$ chromosome to the nucleolus by binding CTCF and maintains H3K27me3 methylation. Genome Biol. 2015, 16, 1-17. [CrossRef] [PubMed]

71. Deng, X.; Ma, W.; Ramani, V.; Hill, A.; Yang, F.; Ay, F.; Berletch, J.B.; Blau, C.A.; Shendure, J.; Duan, Z.; et al. Bipartite structure of the inactive mouse $X$ chromosome. Genome Biol. 2015, 16, 1-21. [CrossRef]

72. Monfort, A.; Wutz, A. The B-side of Xist [version 1; peer review: 3 approved]. F1000Research 2020, 9, 1-12.

73. Fackelmayer, F.; Dahm, K.; Renz, A.; Ramsperger, U.; Richter, A. Nucleic-acid-binding properties of hnRNP-U/SAF-A. Eur. J. Biochem. 1994, 221, 749-757. [CrossRef] [PubMed]

74. Hasegawa, Y.; Brockdorff, N.; Kawano, S.; Tsutui, K.; Tsutui, K.; Nakagawa, S. The matrix protein hnRNP U is required for chromosomal localization of xist RNA. Dev. Cell 2010, 19, 469-476. [CrossRef] [PubMed]

75. Kipp, M.; Göhring, F.; Ostendorp, T.; van Drunen, C.M.; van Driel, R.; Przybylski, M.; Fackelmayer, F.O. SAF-Box, a Conserved Protein Domain That Specifically Recognizes Scaffold Attachment Region DNA. Mol. Cell. Biol. 2000, 20, 7480-7489. [CrossRef]

76. Lv, Q.; Yuan, L.; Song, Y.; Sui, T.; Li, Z.; Lai, L. D-repeat in the XIST gene is required for X chromosome inactivation. RNA Biol. 2016, 13, 172-176. [CrossRef] [PubMed]

77. Hoki, Y.; Kimura, N.; Kanbayashi, M.; Amakawa, Y.; Ohhata, T.; Sasaki, H.; Sado, T. A proximal conserved repeat in the Xist gene is essential as a genomic element for X-inactivation in mouse. Development 2009, 136, 139-146. [CrossRef]

78. Wutz, A.; Rasmussen, T.P.; Jaenisch, R. Chromosomal silencing and localization are mediated by different domains of Xist RNA. Nat. Genet. 2002, 30, 167-174. [CrossRef] 
79. Monfort, A.; Di Minin, G.; Postlmayr, A.; Freimann, R.; Arieti, F.; Thore, S.; Wutz, A. Identification of Spen as a crucial factor for Xist function through forward genetic screening in haploid embryonic stem cells. Cell Rep. 2015, 12, 554-561. [CrossRef]

80. Dossin, F.; Pinheiro, I.; Żylicz, J.J.; Roensch, J.; Collombet, S.; Le Saux, A.; Chelmicki, T.; Attia, M.; Kapoor, V.; Zhan, Y.; et al. SPEN integrates transcriptional and epigenetic control of X-inactivation. Nature 2020, 578, 455-460. [CrossRef]

81. Almeida, M.; Pintacuda, G.; Masui, O.; Koseki, Y.; Gdula, M.; Cerase, A.; Brown, D.; Mould, A.; Innocent, C.; Nakayama, M.; et al PCGF3/5-PRC1 initiates Polycomb recruitment in X chromosome inactivation. Science 2017, 356, 1081-1084. [CrossRef] [PubMed]

82. Lu, Z.; Guo, J.K.; Wei, Y.; Dou, D.R.; Zarnegar, B.; Ma, Q.; Li, R.; Zhao, Y.; Liu, F.; Choudhry, H.; et al. Structural modularity of the XIST ribonucleoprotein complex. Nat. Commun. 2020, 11, 1-14. [CrossRef]

83. Chu, C.; Zhang, Q.C.; da Rocha, S.T.; Flynn, R.A.; Bharadwaj, M.; Calabrese, J.M.; Magnuson, T.; Heard, E.; Chang, H.Y. Systematic discovery of Xist RNA binding proteins. Cell 2015, 161, 404-416. [CrossRef]

84. Minajigi, A.; Froberg, J.; Wei, C.; Sunwoo, H.; Kesner, B.; Colognori, D.; Lessing, D.; Payer, B.; Boukhali, M.; Haas, W.; et al. Chromosomes. A comprehensive Xist interactome reveals cohesin repulsion and an RNA-directed chromosome conformation. Science 2015, 349. [CrossRef] [PubMed]

85. Loda, A.; Heard, E. Xist RNA in action: Past, present, and future. PLoS Genet. 2019, 15, 1-17. [CrossRef]

86. Jégu, T.; Aeby, E.; Lee, J.T. The X chromosome in space. Nat. Rev. Genet. 2017, 18, 377-389. [CrossRef]

87. Giorgetti, L.; Lajoie, B.R.; Carter, A.C.; Attia, M.; Zhan, Y.; Xu, J.; Chen, C.J.; Kaplan, N.; Chang, H.Y.; Heard, E.; et al. Structural organization of the inactive $X$ chromosome in the mouse. Nature 2016, 535, 575-579. [CrossRef]

88. Bischoff, A.; Albers, J.; Kharboush, I.; Stelzer, E.; Cremer, T.; Cremer, C. Differences of size and shape of active and inactive X-chromosome domains in human amniotic fluid cell nuclei. Microsc. Res. Tech. 1993, 25, 68-77. [CrossRef] [PubMed]

89. Eils, R.; Dietzel, S.; Bertin, E.; Schröck, E.; Speicher, M.R.; Ried, T.; Robert-Nicoud, M.; Cremer, C.; Cremer, T. Three-dimensional reconstruction of painted human interphase chromosomes: Active and inactive $\mathrm{X}$ chromosome territories have similar volumes but differ in shape and surface structure. J. Cell Biol. 1996, 135, 1427-1440. [CrossRef]

90. Teller, K.; Illner, D.; Thamm, S.; Casas-Delucchi, C.S.; Versteeg, R.; Indemans, M.; Cremer, T.; Cremer, M. A top-down analysis of $\mathrm{Xa}$ - and $\mathrm{Xi}$-territories reveals differences of higher order structure at $\geq 20 \mathrm{Mb}$ genomic length scales. Nucleus 2011, 2, 465-477. [CrossRef]

91. Kelsey, A.D.; Yang, C.; Leung, D.; Minks, J.; Dixon-McDougall, T.; Baldry, S.E.L.; Bogutz, A.B.; Lefebvre, L.; Brown, C.J. Impact of flanking chromosomal sequences on localization and silencing by the human non-coding RNA XIST. Genome Biol. 2015, 16, 1-16. [CrossRef] [PubMed]

92. BARR, M.L.; BERTRAM, E.G. The behaviour of nuclear structures during depletion and restoration of Nissl material in motor neurons. J. Anat. 1951, 85, 171-17181.

93. Borden, J.; Manuelidis, L. Movement of the X chromosome in epilepsy. Science 1988, 242, 1686-1691. [CrossRef]

94. van Steensel, B.; Belmont, A.S. Lamina-Associated Domains: Links with Chromosome Architecture, Heterochromatin, and Gene Repression. Cell 2017, 169, 780-791. [CrossRef] [PubMed]

95. Berletch, J.B.; Ma, W.; Yang, F.; Shendure, J.; Noble, W.S.; Disteche, C.M.; Deng, X. Escape from X inactivation varies in mouse tissues. PLoS Genet. 2015, 11, e1005079. [CrossRef] [PubMed]

96. Carrel, L.; Willard, H.F. X-inactivation profile reveals extensive variability in X-linked gene expression in females. Nature 2005, 434, 400-404. [CrossRef]

97. Tukiainen, T.; Villani, A.-C.; Yen, A.; Rivas, M.A.; Marshall, J.L.; Satija, R.; Aguirre, M.; Gauthier, L.; Fleharty, M.; Kirby, A.; et al. Landscape of $X$ chromosome inactivation across human tissues. Nature 2017, 550, 244-248. [CrossRef] [PubMed]

98. Murakami, K.; Ohhira, T.; Oshiro, E.; Qi, D.; Oshimura, M.; Kugoh, H. Identification of the chromatin regions coated by non-coding Xist RNA. Cytogenet. Genome Res. 2009, 125, 19-25. [CrossRef]

99. Filippova, G.N.; Cheng, M.K.; Moore, J.M.; Truong, J.P.; Hu, Y.J.; Nguyen, D.K.; Tsuchiya, K.D.; Disteche, C.M. Boundaries between chromosomal domains of $\mathrm{X}$ inactivation and escape bind CTCF and lack CpG methylation during early development. Dev. Cell 2005, 8, 31-42. [CrossRef]

100. Chen, C.Y.; Shi, W.; Balaton, B.P.; Matthews, A.M.; Li, Y.; Arenillas, D.J.; Mathelier, A.; Itoh, M.; Kawaji, H.; Lassmann, T.; et al. YY1 binding association with sex-biased transcription revealed through $\mathrm{X}$-linked transcript levels and allelic binding analyses. Sci. Rep. 2016, 6, 1-14. [CrossRef] [PubMed]

101. Fang, H.; Disteche, C.M.; Berletch, J.B. X Inactivation and Escape: Epigenetic and Structural Features. Front. Cell Dev. Biol. 2019, 7, 1-12. [CrossRef] [PubMed]

102. Reinius, B.; Shi, C.; Hengshuo, L.; Sandhu, K.S.; Radomska, K.J.; Rosen, G.D.; Lu, L.; Kullander, K.; Williams, R.W.; Jazin, E. Female-biased expression of long non-coding RNAs in domains that escape X-inactivation in mouse. BMC Genomics 2010, 11. [CrossRef] [PubMed]

103. Neri, G.; Schwartz, C.E.; Lubs, H.A.; Stevenson, R.E. X-linked intellectual disability update 2017. Am. J. Med. Genet. A 2018, 176, 1375-1388. [CrossRef] [PubMed]

104. Nguyen, D.K.; Disteche, C.M. Dosage compensation of the active X chromosome in mammals. Nat. Genet. 2006, 38 , 47-53. [CrossRef]

105. Nguyen, D.K.; Disteche, C.M. High expression of the mammalian X chromosome in brain. Brain Res. 2006, 1126, 46-49. [CrossRef] 
106. Scandaglia, M.; Lopez-Atalaya, J.P.; Medrano-Fernandez, A.; Lopez-Cascales, M.T.; del Blanco, B.; Lipinski, M.; Benito, E.; Olivares, R.; Iwase, S.; Shi, Y.; et al. Loss of Kdm5c Causes Spurious Transcription and Prevents the Fine-Tuning of Activity-Regulated Enhancers in Neurons. Cell Rep. 2017, 21, 47-59. [CrossRef]

107. Jensen, L.R.; Amende, M.; Gurok, U.; Moser, B.; Gimmel, V.; Tzschach, A.; Janecke, A.R.; Tariverdian, G.; Chelly, J.; Fryns, J.P.; et al. Mutations in the JARID1C gene, which is involved in transcriptional regulation and chromatin remodeling, cause X-linked mental retardation. Am. J. Hum. Genet. 2005, 76, 227-236. [CrossRef]

108. Claes, S.; Devriendt, K.; Van Goethem, G.; Roelen, L.; Meireleire, J.; Raeymaekers, P.; Cassiman, J.J.; Fryns, J.P. Novel syndromic form of X-linked complicated spastic paraplegia. Am. J. Med. Genet. 2000, 94, 1-4. [CrossRef]

109. Ji, B.; Higa, K.K.; Kelsoe, J.R.; Zhou, X. Over-expression of XIST, the Master Gene for X Chromosome Inactivation, in Females With Major Affective Disorders. EBioMedicine 2015, 2, 909-918. [CrossRef]

110. Yu, S.; Chen, C.; Pan, Y.; Kurz, M.C.; Datner, E.; Hendry, P.L.; Velilla, M.-A.; Lewandowski, C.; Pearson, C.; Domeier, R.; et al. Genes known to escape $\mathrm{X}$ chromosome inactivation predict co-morbid chronic musculoskeletal pain and posttraumatic stress symptom development in women following trauma exposure. Am. J. Med. Genet. B Neuropsychiatr. Genet. 2019, 180, $415-427$. [CrossRef]

111. Hong, D.S.; Reiss, A.L. Cognition and behavior in turner syndrome: A brief review. Pediatr. Endocrinol. Rev. 2012, 9, 710-712. [PubMed]

112. Clement-Jones, M.; Schiller, S.; Rao, E.; Blaschke, R.J.; Zuniga, A.; Zeller, R.; Robson, S.C.; Binder, G.; Glass, I.; Strachan, T.; et al. The short stature homeobox gene SHOX is involved in skeletal abnormalities in Turner syndrome. Hum. Mol. Genet. 2000, 9 , 695-702. [CrossRef] [PubMed]

113. Trolle, C.; Nielsen, M.M.; Skakkebæk, A.; Lamy, P.; Vang, S.; Hedegaard, J.; Nordentoft, I.; Ørntoft, T.F.; Pedersen, J.S.; Gravholt, C.H. Widespread DNA hypomethylation and differential gene expression in Turner syndrome. Sci. Rep. 2016, 6, 1-14. [CrossRef]

114. Kuntsi, J.; Skuse, D.; Elgar, K.; Morris, E.; Turner, C. Ring-X chromosomes: Their cognitive and behavioural phenotype. Ann. Hum. Genet. 2000. [CrossRef]

115. Viana, J.; Pidsley, R.; Troakes, C.; Spiers, H.; Wong, C.C.Y.; Al-Sarraj, S.; Craig, I.; Schalkwyk, L.; Mill, J. Epigenomic and transcriptomic signatures of a Klinefelter syndrome (47,XXY) karyotype in the brain. Epigenetics 2014, 9, 587-599. [CrossRef]

116. Zhang, X.; Yang, J.; Li, Y.; Ma, X.; Li, R. Sex chromosome abnormalities and psychiatric diseases. Oncotarget 2017, 8, 3969-3979. [CrossRef]

117. Navarro-Cobos, M.J.; Balaton, B.P.; Brown, C.J. Genes that escape from X-chromosome inactivation: Potential contributors to Klinefelter syndrome. Am. J. Med. Genet. C Semin. Med. Genet. 2020, 184, 226-238. [CrossRef]

118. Clemson, C.M.; Hutchinson, J.N.; Sara, S.A.; Ensminger, A.W.; Fox, A.H.; Chess, A.; Lawrence, J.B. An Architectural Role for a Nuclear Noncoding RNA: NEAT1 RNA Is Essential for the Structure of Paraspeckles. Mol. Cell 2009, 33, 717-726. [CrossRef] [PubMed]

119. Naganuma, T.; Nakagawa, S.; Tanigawa, A.; Sasaki, Y.F.; Goshima, N.; Hirose, T. Alternative $3^{\prime}$-end processing of long noncoding RNA initiates construction of nuclear paraspeckles. EMBO J. 2012, 31, 4020-4034. [CrossRef]

120. Sunwoo, H.; Dinger, M.E.; Wilusz, J.E.; Amaral, P.P.; Mattick, J.S.; Spector, D.L. Men $\varepsilon / \beta$ nuclear-retained non-coding RNAs are up-regulated upon muscle differentiation and are essential components of paraspeckles. Genome Res. 2009, 19, 347-359. [CrossRef]

121. Sasaki, Y.T.F.; Ideue, T.; Sano, M.; Mituyama, T.; Hirose, T. MEN $\varepsilon$ / $\beta$ noncoding RNAs are essential for structural integrity of nuclear paraspeckles. Proc. Natl. Acad. Sci. USA 2009, 106, 2525-2530. [CrossRef]

122. Chen, L.-L.; Carmichael, G.G. Altered Nuclear Retention of mRNAs Containing Inverted Repeats in Human Embryonic Stem Cells: Functional Role of a Nuclear Noncoding RNA. Mol. Cell 2009, 35, 467-478. [CrossRef] [PubMed]

123. Nakagawa, S.; Naganuma, T.; Shioi, G.; Hirose, T. Paraspeckles are subpopulation-specific nuclear bodies that are not essential in mice. J. Cell Biol. 2011, 193, 31-39. [CrossRef] [PubMed]

124. Chujo, T.; Yamazaki, T.; Kawaguchi, T.; Kurosaka, S.; Takumi, T.; Nakagawa, S.; Hirose, T. Unusual semi-extractability as a hallmark of nuclear body-associated architectural noncoding RNAs. EMBO J. 2017, 36, 1447-1462. [CrossRef] [PubMed]

125. Knott, G.J.; Bond, C.S.; Fox, A.H. The DBHS proteins SFPQ, NONO and PSPC1: A multipurpose molecular scaffold. Nucleic Acids Res. 2016, 44, 3989-4004. [CrossRef] [PubMed]

126. Passon, D.M.; Lee, M.; Rackham, O.; Stanley, W.A.; Sadowska, A.; Filipovska, A.; Fox, A.H.; Bond, C.S. Structure of the heterodimer of human NONO and paraspeckle protein component 1 and analysis of its role in subnuclear body formation. Proc. Natl. Acad. Sci. USA 2012, 109, 4846-4850. [CrossRef]

127. Hennig, S.; Kong, G.; Mannen, T.; Sadowska, A.; Kobelke, S.; Blythe, A.; Knott, G.J.; Iyer, S.S.; Ho, D.; Newcombe, E.A.; et al. Prion-like domains in RNA binding proteins are essential for building subnuclear paraspeckles. J. Cell Biol. 2015, 210, 529-539. [CrossRef]

128. Maharana, S.; Wang, J.; Papadopoulos, D.K.; Richter, D.; Pozniakovsky, A.; Poser, I.; Bickle, M.; Rizk, S.; Guillén-Boixet, J.; Franzmann, T.M.; et al. RNA buffers the phase separation behavior of prion-like RNA binding proteins. Science 2018, 360, 918-921. [CrossRef]

129. Mao, Y.S.; Sunwoo, H.; Zhang, B.; Spector, D.L. Direct visualization of the co-transcriptional assembly of a nuclear body by noncoding RNAs. Nat. Cell Biol. 2011, 13, 95-101. [CrossRef] [PubMed] 
130. Wang, Z.; Li, K.; Huang, W. Long non-coding RNA NEAT1-centric gene regulation. Cell. Mol. Life Sci. 2020, $77,3769-3779$. [CrossRef]

131. Yamazaki, T.; Souquere, S.; Chujo, T.; Kobelke, S.; Chong, Y.S.; Fox, A.H.; Bond, C.S.; Nakagawa, S.; Pierron, G.; Hirose, T. Functional Domains of NEAT1 Architectural lncRNA Induce Paraspeckle Assembly through Phase Separation. Mol. Cell 2018, 70, 1038-1053.e7. [CrossRef]

132. West, J.A.; Mito, M.; Kurosaka, S.; Takumi, T.; Tanegashima, C.; Chujo, T.; Yanaka, K.; Kingston, R.E.; Hirose, T.; Bond, C.; et al. Structural, super-resolution microscopy analysis of paraspeckle nuclear body organization. J. Cell Biol. 2016, 214, 817-830. [CrossRef]

133. Kawaguchi, T.; Tanigawa, A.; Naganuma, T.; Ohkawa, Y.; Souquere, S.; Pierron, G.; Hirose, T. SWI/SNF chromatin-remodeling complexes function in noncoding RNA-dependent assembly of nuclear bodies. Proc. Natl. Acad. Sci. USA 2015, 112, 4304-4309. [CrossRef] [PubMed]

134. Hirose, T.; Virnicchi, G.; Tanigawa, A.; Naganuma, T.; Li, R.; Kimura, H.; Yokoi, T.; Nakagawa, S.; Bénard, M.; Fox, A.H.; et al. NEAT1 long noncoding RNA regulates transcription via protein sequestration within subnuclear bodies. Mol. Biol. Cell 2014, 25, 169-183. [CrossRef]

135. West, J.A.; Davis, C.P.; Sunwoo, H.; Simon, M.D.; Sadreyev, R.I.; Wang, P.I.; Tolstorukov, M.Y.; Kingston, R.E. The Long Noncoding RNAs NEAT1 and MALAT1 Bind Active Chromatin Sites. Mol. Cell 2014, 55, 791-802. [CrossRef]

136. Chakravarty, D.; Sboner, A.; Nair, S.S.; Giannopoulou, E.; Li, R.; Hennig, S.; Mosquera, J.M.; Pauwels, J.; Park, K.; Kossai, M.; et al. The oestrogen receptor alpha-regulated lncRNA NEAT1 is a critical modulator of prostate cancer. Nat. Commun. 2014, 5 . [CrossRef] [PubMed]

137. Grosch, M.; Ittermann, S.; Rusha, E.; Greisle, T.; Ori, C.; Truong, D.J.J.; O’Neill, A.C.; Pertek, A.; Westmeyer, G.G.; Drukker, M. Nucleus size and DNA accessibility are linked to the regulation of paraspeckle formation in cellular differentiation. BMC Biol. 2020, 18, 42. [CrossRef]

138. Imamura, K.; Imamachi, N.; Akizuki, G.; Kumakura, M.; Kawaguchi, A.; Nagata, K.; Kato, A.; Kawaguchi, Y.; Sato, H.; Yoneda, M.; et al. Long Noncoding RNA NEAT1-Dependent SFPQ Relocation from Promoter Region to Paraspeckle Mediates IL8 Expression upon Immune Stimuli. Mol. Cell 2014, 53, 393-406. [CrossRef] [PubMed]

139. Zhao, J.; He, L.; Yin, L. lncRNA NEAT1 Binds to MiR-339-5p to Increase HOXA1 and Alleviate Ischemic Brain Damage in Neonatal Mice. Mol. Ther. Nucleic Acid 2020, 20, 117-127. [CrossRef] [PubMed]

140. Li, J.-W.; Ren, S.-H.; Ren, J.-R.; Zhen, Z.-G.; Li, L.-R.; Hao, X.-D.; Ji, H.-M. Nimodipine Improves Cognitive Impairment After Subarachnoid Hemorrhage in Rats Through IncRNA NEAT1/miR-27a/MAPT Axis. Drug Des. Dev. Ther. 2020, 14, $2295-2306$. [CrossRef]

141. Jiang, L.; Shao, C.; Wu, Q.J.; Chen, G.; Zhou, J.; Yang, B.; Li, H.; Gou, L.T.; Zhang, Y.; Wang, Y.; et al. NEAT1 scaffolds RNA-binding proteins and the Microprocessor to globally enhance pri-miRNA processing. Nat. Struct. Mol. Biol. 2017, 24, 816-824. [CrossRef] [PubMed]

142. Wang, Z.; Fan, P.; Zhao, Y.; Zhang, S.; Lu, J.; Xie, W.; Jiang, Y.; Lei, F.; Xu, N.; Zhang, Y. NEAT1 modulates herpes simplex virus-1 replication by regulating viral gene transcription. Cell. Mol. Life Sci. 2017, 74, 1117-1131. [CrossRef] [PubMed]

143. Pisani, G.; Baron, B. Nuclear paraspeckles function in mediating gene regulatory and apoptotic pathways. Non-coding RNA Res. 2019, 4, 128-134. [CrossRef] [PubMed]

144. Nishimoto, Y.; Nakagawa, S.; Hirose, T.; Okano, H.J.; Takao, M.; Shibata, S.; Suyama, S.; Kuwako, K.I.; Imai, T.; Murayama, S.; et al. The long non-coding RNA nuclear-enriched abundant transcript 1-2 induces paraspeckle formation in the motor neuron during the early phase of amyotrophic lateral sclerosis. Mol. Brain 2013, 6, 1-18. [CrossRef]

145. Butler, A.A.; Johnston, D.R.; Kaur, S.; Lubin, F.D. Long noncoding RNA NEAT1 mediates neuronal histone methylation and age-related memory impairment. Sci. Signal. 2019, 12. [CrossRef]

146. Kukharsky, M.S.; Ninkina, N.N.; An, H.; Telezhkin, V.; Wei, W.; de Meritens, C.R.; Cooper-knock, J.; Nakagawa, S.; Hirose, T.; Buchman, V.L.; et al. Long non-coding RNA Neat1 regulates adaptive behavioural response to stress in mice. Transl. Psychiatry 2020, 10, 1-19. [CrossRef]

147. Nakagawa, S.; Shimada, M.; Yanaka, K.; Mito, M.; Arai, T.; Takahashi, E.; Fujita, Y.; Fujimori, T.; Standaert, L.; Marine, J.C.; et al. The lncRNA Neat1 is required for corpus luteum formation and the establishment of pregnancy in a subpopulation of mice. Development 2014, 141, 4618-4627. [CrossRef]

148. Cheng, C.; Spengler, R.M.; Keiser, M.S.; Monteys, A.M.; Rieders, J.M.; Ramachandran, S.; Davidson, B.L. The long non-coding RNA NEAT1 is elevated in polyglutamine repeat expansion diseases and protects from disease gene-dependent toxicities. Hum. Mol. Genet. 2018, 27, 4303-4314. [CrossRef]

149. Lipovich, L.; Dachet, F.; Cai, J.; Bagla, S.; Balan, K.; Jia, H.; Loeb, J.A. Activity-dependent human brain coding/noncoding gene regulatory networks. Genetics 2012, 192, 1133-1148. [CrossRef]

150. Barry, G.; Briggs, J.A.; Hwang, D.W.; Nayler, S.P.; Fortuna, P.R.J.; Jonkhout, N.; Dachet, F.; Maag, J.L.V.; Mestdagh, P.; Singh, E.M.; et al. The long non-coding RNA NEAT1 is responsive to neuronal activity and is associated with hyperexcitability states. Sci. Rep. 2017, 7, 40127. [CrossRef]

151. Pongs, O. Regulation of excitability by potassium channels. Results Probl. Cell Differ. 2007, 44, 145-161. [CrossRef]

152. Pereira Fernandes, D.; Bitar, M.; Jacobs, F.; Barry, G. Long Non-Coding RNAs in Neuronal Aging. Non-Coding RNA 2018, 4, 12. [CrossRef] 
153. Barry, G.; Guennewig, B.; Fung, S.; Kaczorowski, D.; Weickert, C.S. Long non-coding RNA expression during aging in the human subependymal zone. Front. Neurol. 2015, 6, 1-10. [CrossRef]

154. Suzuki, H.; Shibagaki, Y.; Hattori, S.; Matsuoka, M. C9-ALS/FTD-linked proline-arginine dipeptide repeat protein associates with paraspeckle components and increases paraspeckle formation. Cell Death Dis. 2019, 10, 746. [CrossRef] [PubMed]

155. Harley, J.; Patani, R. Stress-Specific Spatiotemporal Responses of RNA-Binding Proteins in Human Stem Cell-Derived Motor Neurons. Int. J. Mol. Sci. 2020, 21, 8346. [CrossRef] [PubMed]

156. Koza, P.; Beroun, A.; Konopka, A.; Górkiewicz, T.; Bijoch, L.; Torres, J.C.; Bulska, E.; Knapska, E.; Kaczmarek, L.; Konopka, W. Neuronal TDP-43 depletion affects activity-dependent plasticity. Neurobiol. Dis. 2019, 130, 104499. [CrossRef] [PubMed]

157. Tollervey, J.R.; Curk, T.; Rogelj, B.; Briese, M.; Cereda, M.; Kayikci, M.; Hortobágyi, T.; Nishimura, A.L.; Župunski, V.; Patani, R.; et al. Characterising the RNA targets and position-dependent splicing regulation by TDP-43; implications for neurodegenerative diseases Europe PMC Funders Group. Nat. Neurosci. 2011, 14, 452-458. [CrossRef]

158. Wang, Z.; Zhao, Y.; Xu, N.; Zhang, S.; Wang, S.; Mao, Y.; Zhu, Y.; Li, B.; Jiang, Y.; Tan, Y.; et al. NEAT1 regulates neuroglial cell mediating A $\beta$ clearance via the epigenetic regulation of endocytosis-related genes expression. Cell. Mol. Life Sci. 2019, 76, 3005-3018. [CrossRef]

159. Shelkovnikova, T.A.; Kukharsky, M.S.; An, H.; Dimasi, P.; Alexeeva, S.; Shabir, O.; Heath, P.R.; Buchman, V.L. Protective paraspeckle hyper-assembly downstream of TDP-43 loss of function in amyotrophic lateral sclerosis. Mol. Neurodegener. 2018, 13, 1-17. [CrossRef]

160. Ji, P.; Diederichs, S.; Wang, W.; Boïng, S.; Metzger, R.; Schneider, P.M.; Tidow, N.; Brandt, B.; Buerger, H.; Bulk, E.; et al. MALAT-1, a novel noncoding RNA, and thymosin b4 predict metastasis and survival in early-stage non-small cell lung cancer. Oncogene 2003, 22, 8031-8041. [CrossRef]

161. Johnsson, P.; Lipovich, L.; Grandér, D.; Morris, K.V. Evolutionary conservation of long non-coding RNAs; Sequence, structure, function. Biochim. Biophys. Acta Gen. Subj. 2014, 1840, 1063-1071. [CrossRef] [PubMed]

162. Tripathi, V.; Ellis, J.D.; Shen, Z.; Song, D.Y.; Pan, Q.; Watt, A.T.; Freier, S.M.; Bennett, C.F.; Sharma, A.; Bubulya, P.A.; et al. The Nuclear-Retained Noncoding RNA MALAT1 Regulates Alternative Splicing by Modulating SR Splicing Factor Phosphorylation. Mol. Cell 2010, 39, 925-938. [CrossRef]

163. Lamond, A.I.; Spector, D.L. Nuclear speckles: A model for nuclear organelles. Nat. Rev. Mol. Cell Biol. 2003, 4, 605-612. [CrossRef]

164. O'Keefe, R.T.; Henderson, S.C.; Spector, D.L. Dynamic organization of DNA replication in mammalian cell nuclei: Spatially and temporally defined replication of chromosome-specific $\alpha$-satellite DNA sequences. J. Cell Biol. 1992, 116, 1095-1110. [CrossRef] [PubMed]

165. Spector, D.L.; Fu, X.D.; Maniatis, T. Associations between distinct pre-mRNA splicing components and the cell nucleus. EMBO J. 1991, 10, 3467-3481. [CrossRef] [PubMed]

166. Kim, J.; Han, K.Y.; Khanna, N.; Ha, T.; Belmont, A.S. Nuclear speckle fusion via long-range directional motion regulates speckle morphology after transcriptional inhibition. J. Cell Sci. 2019, 132. [CrossRef] [PubMed]

167. Galganski, L.; Urbanek, M.O.; Krzyzosiak, W.J. Nuclear speckles: Molecular organization, biological function and role in disease. Nucleic Acids Res. 2017, 45, 10350-10368. [CrossRef]

168. Shopland, L.S.; Johnson, C.V.; Lawrence, J.B. Evidence that all SC-35 domains contain mRNAs and that transcripts can be structurally constrained within these domains. J. Struct. Biol. 2002, 140, 131-139. [CrossRef]

169. Carter, K.C.; Taneja, K.L.; Lawrence, J.B. Discrete nuclear domains of poly(A) RNA and their relationship to the functional organization of the nucleus. J. Cell Biol. 1991, 115, 1191-1202. [CrossRef] [PubMed]

170. Fei, J.; Jadaliha, M.; Harmon, T.S.; Li, I.T.S.; Hua, B.; Hao, Q.; Holehouse, A.S.; Reyer, M.; Sun, Q.; Freier, S.M.; et al. Quantitative analysis of multilayer organization of proteins and RNA in nuclear speckles at super resolution. J. Cell Sci. 2017, 130, 4180-4192 [CrossRef]

171. Rieder, D.; Ploner, C.; Krogsdam, A.M.; Stocker, G.; Fischer, M.; Scheideler, M.; Dani, C.; Amri, E.-Z.; Müller, W.G.; Mcnally, J.G.; et al. Co-expressed genes prepositioned in spatial neighborhoods stochastically associate with SC35 speckles and RNA polymerase II factories. Cell. Mol. Life Sci. 2014, 71, 1741-1759. [CrossRef]

172. Xing, Y.; Johnson, C.V.; Moen, P.T.; McNeil, J.A.; Lawrence, J.B. Nonrandom gene organization: Structural arrangements of specific pre-mRNA transcription and splicing with SC-35 domains. J. Cell Biol. 1995, 131, 1635-1647. [CrossRef] [PubMed]

173. Szczerbal, I.; Bridger, J.M. Association of adipogenic genes with SC-35 domains during porcine adipogenesis. Chromosome Res. 2010, 18, 887-895. [CrossRef]

174. Jolly, C.; Vourc'h, C.; Robert-Nicoud, M.; Morimoto, R.I. Intron-independent association of splicing factors with active genes. J. Cell Biol. 1999, 145, 1133-1143. [CrossRef] [PubMed]

175. Smith, K.P.; Moen, P.T.; Wydner, K.L.; Coleman, J.R.; Lawrence, J.B. Processing of endogenous pre-mRNAs in association with SC-35 domains is gene specific. J. Cell Biol. 1999, 144, 617-629. [CrossRef] [PubMed]

176. Moen, P.T.; Johnson, C.V.; Byron, M.; Shopland, L.S.; De La Serna, I.L.; Imbalzano, A.N.; Lawrence, J.B. Repositioning of Muscle-specific Genes Relative to the Periphery of SC-35 Domains during Skeletal Myogenesis. Mol. Biol. Cell 2004, 15, 197-206. [CrossRef] [PubMed]

177. Brown, J.M.; Leach, J.; Reittie, J.E.; Atzberger, A.; Lee-Prudhoe, J.; Wood, W.G.; Higgs, D.R.; Iborra, F.J.; Buckle, V.J. Coregulated human globin genes are frequently in spatial proximity when active. J. Cell Biol. 2006, 172, 177-187. [CrossRef] [PubMed] 
178. Brown, J.M.; Green, J.; Das Neves, R.P.; Wallace, H.A.C.; Smith, A.J.H.; Hughes, J.; Gray, N.; Taylor, S.; Wood, W.G.; Higgs, D.R.; et al. Association between active genes occurs at nuclear speckles and is modulated by chromatin environment. J. Cell Biol. 2008, 182, 1083-1097. [CrossRef]

179. Nielsen, J.A.; Hudson, L.D.; Armstrong, R.C. Nuclear organization in differentiating oligodendrocytes. J. Cell Sci. 2002, 115, 4071-4079. [CrossRef]

180. Kim, J.; Venkata, N.C.; Hernandez Gonzalez, G.A.; Khanna, N.; Belmont, A.S. Gene expression amplification by nuclear speckle association. J. Cell Biol. 2019, 219, e201904046. [CrossRef]

181. Quinodoz, S.A.; Ollikainen, N.; Tabak, B.; Palla, A.; Schmidt, J.M.; Detmar, E.; Lai, M.M.; Shishkin, A.A.; Bhat, P.; Takei, Y.; et al. Higher-Order Inter-chromosomal Hubs Shape 3D Genome Organization in the Nucleus. Cell 2018, 174, 744-757.e24. [CrossRef]

182. Chen, Y.; Zhang, Y.; Wang, Y.; Zhang, L.; Brinkman, E.K.; Adam, S.A.; Goldman, R.; Van Steensel, B.; Ma, J.; Belmont, A.S. Mapping 3D genome organization relative to nuclear compartments using TSA-Seq as a cytological ruler. J. Cell Biol. 2018, 217, 4025-4048. [CrossRef]

183. Romero-Barrios, N.; Legascue, M.F.; Benhamed, M.; Ariel, F.; Crespi, M. Splicing regulation by long noncoding RNAs. Nucleic Acids Res. 2018, 46, 2169-2184. [CrossRef]

184. Kataoka, N.; Fujita, M.; Ohno, M. Functional Association of the Microprocessor Complex with the Spliceosome. Mol. Cell. Biol. 2009, 29, 3243-3254. [CrossRef]

185. Nakagawa, S.; Ip, J.Y.; Shioi, G.; Tripathi, V.; Zong, X.; Hirose, T.; Prasanth, K. V Malat1 is not an essential component of nuclear speckles in mice. RNA 2012, 18, 1487-1499. [CrossRef]

186. Zhang, B.; Arun, G.; Mao, Y.S.; Lazar, Z.; Hung, G.; Bhattacharjee, G.; Xiao, X.; Booth, C.J.; Wu, J.; Zhang, C.; et al. The lncRNA Malat1 Is Dispensable for Mouse Development but Its Transcription Plays a cis-Regulatory Role in the Adult. Cell Rep. 2012, 2, 111-123. [CrossRef] [PubMed]

187. Nguyen, T.M.; Kabotyanski, E.B.; Reineke, L.C.; Shao, J.; Xiong, F.; Lee, J.-H.; Dubrulle, J.; Johnson, H.; Stossi, F.; Tsoi, P.S.; et al. The SINEB1 element in the long non-coding RNA Malat1 is necessary for TDP-43 proteostasis. Nucleic Acids Res. 2019, 48, 2621-2642. [CrossRef] [PubMed]

188. Tani, H.; Okuda, S.; Nakamura, K.; Aoki, M.; Umemura, T. Short-lived long non-coding RNAs as surrogate indicators for chemical exposure and LINC00152 and MALAT1 modulate their neighboring genes. PLoS One 2017, 12. [CrossRef]

189. Yang, L.; Lin, C.; Liu, W.; Zhang, J.; Ohgi, K.A.; Grinstein, J.D.; Dorrestein, P.C.; Rosenfeld, M.G. NcRNA- and Pc2 methylationdependent gene relocation between nuclear structures mediates gene activation programs. Cell 2011, 147, 773-788. [CrossRef] [PubMed]

190. Medrano-Fernández, A.; Barco, A. Nuclear organization and 3D chromatin architecture in cognition and neuropsychiatric disorders. Mol. Brain 2016, 9, 1-12. [CrossRef]

191. Navascues, J.; Casafont, I.; Villagra, N.T.; Lafarga, M.; Berciano, M.T. Reorganization of nuclear compartments of type A neurons of trigeminal ganglia in response to inflammatory injury of peripheral nerve endings. J. Neurocytol. 2004, 33, 393-405. [CrossRef] [PubMed]

192. Meng, C.; Yang, X.; Liu, Y.; Zhou, Y.; Rui, J.; Li, S.; Xu, C.; Zhuang, Y.; Lao, J.; Zhao, X. Decreased expression of lncRNA Malat1 in rat spinal cord contributes to neuropathic pain by increasing neuron excitability after brachial plexus avulsion. J. Pain Res. 2019, 12, 1297-1310. [CrossRef] [PubMed]

193. Jiang, T.; Cai, Z.; Ji, Z.; Zou, J.; Liang, Z.; Zhang, G.; Liang, Y.; Lin, H.; Tan, M. The lncRNA MALAT1/miR-30/Spastin Axis Regulates Hippocampal Neurite Outgrowth. Front. Cell. Neurosci. 2020, 14. [CrossRef] [PubMed]

194. Guo, D.; Ma, J.; Yan, L.; Li, T.; Li, Z.; Han, X.; Shui, S. Down-Regulation of Lncrna MALAT1 Attenuates Neuronal Cell Death Through Suppressing Beclin1-Dependent Autophagy by Regulating Mir-30a in Cerebral Ischemic Stroke. Cell. Physiol. Biochem. 2017, 43, 182-194. [CrossRef]

195. Wu, Q.; Yi, X. Down-regulation of Long Noncoding RNA MALAT1 Protects Hippocampal Neurons Against Excessive Autophagy and Apoptosis via the PI3K/Akt Signaling Pathway in Rats with Epilepsy. J. Mol. Neurosci. 2018, 65, 234-245. [CrossRef]

196. Liu, W.; Zhang, Q.; Zhang, J.; Pan, W.; Zhao, J.; Xu, Y. Long non-coding RNA MALAT1 contributes to cell apoptosis by sponging miR-124 in Parkinson disease. Cell Biosci. 2017, 7, 19. [CrossRef]

197. Li, L.; Xu, Y.; Zhao, M.; Gao, Z. Neuro-protective roles of long non-coding RNA MALAT1 in Alzheimer's disease with the involvement of the microRNA-30b/CNR1 network and the following PI3K/AKT activation. Exp. Mol. Pathol. $2020,117$. [CrossRef] [PubMed]

198. Ma, P.; Li, Y.; Zhang, W.; Fang, F.; Sun, J.; Liu, M.; Li, K.; Dong, L. Long Non-coding RNA MALAT1 Inhibits Neuron Apoptosis and Neuroinflammation While Stimulates Neurite Outgrowth and Its Correlation With MiR-125b Mediates PTGS2, CDK5 and FOXQ1 in Alzheimer's Disease. Curr. Alzheimer Res. 2019, 16, 596-612. [CrossRef]

199. Rapicavoli, N.A.; Poth, E.M.; Blackshaw, S. The long noncoding RNA RNCR2 directs mouse retinal cell specification. BMC Dev. Biol. 2010, 10. [CrossRef]

200. Mercer, T.R.; Qureshi, I.A.; Gokhan, S.; Dinger, M.E.; Li, G.; Mattick, J.S.; Mehler, M.F. Long noncoding RNAs in neuronal-glial fate specification and oligodendrocyte lineage maturation. BMC Neurosci. 2010, 11, 14. [CrossRef]

201. Mercer, T.R.; Dinger, M.E.; Sunkin, S.M.; Mehler, M.F.; Mattick, J.S. Specific expression of long noncoding RNAs in the mouse brain. Proc. Natl. Acad. Sci. USA 2008, 105, 716-721. [CrossRef] [PubMed] 
202. Aprea, J.; Prenninger, S.; Dori, M.; Ghosh, T.; Monasor, L.S.; Wessendorf, E.; Zocher, S.; Massalini, S.; Alexopoulou, D.; Lesche, M.; et al. Transcriptome sequencing during mouse brain development identifies long non-coding RNAs functionally involved in neurogenic commitment. EMBO J. 2013, 32, 3145-3160. [CrossRef]

203. Stilling, R.M.; Benito, E.; Gertig, M.; Barth, J.; Capece, V.; Burkhardt, S.; Bonn, S.; Fischer, A. De-regulation of gene expression and alternative splicing affects distinct cellular pathways in the aging hippocampus. Front. Cell. Neurosci. 2014, 8, 1-15. [CrossRef]

204. Michelhaugh, S.K.; Lipovich, L.; Blythe, J.; Jia, H.; Kapatos, G.; Bannon, M.J. Mining Affymetrix microarray data for long non-coding RNAs: Altered expression in the nucleus accumbens of heroin abusers. J. Neurochem. 2011, 116, 459-466. [CrossRef] [PubMed]

205. Ip, J.Y.; Sone, M.; Nashiki, C.; Pan, Q.; Kitaichi, K.; Yanaka, K.; Abe, T.; Takao, K.; Miyakawa, T.; Blencowe, B.J.; et al. Gomafu lncRNA knockout mice exhibit mild hyperactivity with enhanced responsiveness to the psychostimulant methamphetamine. Sci. Rep. 2016, 6, 1-13. [CrossRef] [PubMed]

206. Barry, G.; Briggs, J.A.; Vanichkina, D.P.; Poth, E.M.; Beveridge, N.J.; Ratnu, V.S.; Nayler, S.P.; Nones, K.; Hu, J.; Bredy, T.W.; et al. The long non-coding RNA Gomafu is acutely regulated in response to neuronal activation and involved in schizophreniaassociated alternative splicing. Mol. Psychiatry 2014, 19, 486-494. [CrossRef] [PubMed] 